\title{
Sürdürülebilir Turizm: Alaçatı Destinasyonuna Yönelik Bir Uygulama
}

\author{
Sustainable Tourism: An Application for Alaçatı Destination
}

Ceylan ALKAN, Yaşar Üniversitesi, Türkiye, ceylan.erdogan@yasar.edu.tr

\begin{abstract}
Öz: Ülkelerin sahip olduğu doğal ve sosyo-kültürel kaynaklar, turistleri destinasyonlara çeken en önemli faktörler olarak kabul edilmektedir. Bu kaynaklarda meydana gelecek tahribatlar kimi zaman geri dönüşümü olmayan sonuçlara neden olmaktadır. Sürdürülebilirlik kavramının destinasyonlar tarafindan anlaşlmaslyla ve alınacak bir takım önemlerle bu tahribatın önüne geçilmektedir. Bu çalışma, Alaçatı destinasyonunun sahip olduğu turistik çekiciliklerin sürdürülebilirliğinin irdelenmesi amact ile yapılmıştır. Araş̧tırma nitel veri toplama araçlarından yarı yapılandırılmış görüş̧me tekniği ile gerçekleștirilmişstir. Araşstırmada sivil toplum kuruluşlart, yerel yönetim ve işletme yöneticileri olmak üzere toplam 15 kişi ile görüşülmüsşür. Araşstrma sonucunda, destinasyonun kaynaklarının sürdürülebilirliği için özel sektör, kamu sektörü ve sivil toplum kuruluşlarının işbirliği çerçevesinde ortak fikir üretilerek uygulamaya geçilmesi gerekliliği tespit edilmiştir.
\end{abstract}

Anahtar Kelimeler: Sürdürülebilir Turizm, Destinasyon, Yarı Yapılandırılmış Görüşme Tekniği, Alaçatı

Abstract: Natural beauties and socio-cultural resources of countries are the main factors for attracting tourists to these tourist destinations. Any destruction on these resources may cause irreversible damages on tourism industry. Sustainability concept in tourism is very important and irreversible damages on touristic and natural resources may be avoidable by taking some precautions. Main objective of this study is to examine and disccuss the sustainability of tourism attraction of Alaçat, İzmir. The study was conducted by using interviewing technique of qualitative data collection tools. In the study, a total of 15 people including non-governmental organizations, local authorities, and private business managers of tourism sector were interviewed. The study has shown that for sustainable advancement of tourism resources of Alaçatı, collaboration and continuous efforts of these three sectors: goverment, non-government asssociations and, private companies are necessary for debating coming issues, generating new ideas and solving any problems before it has become an unrecoverable scale.

Keywords: Sustainable Tourism, Destination, Semi-Structured Interwiev Technique, Alaçatı

\section{Giriş}

Turizm, gelişmekte olan ülkelerin en önemli gelir kaynaklarından biri olarak kabul edilmektedir. Gelişmekte olan ülkeler sahip oldukları doğal ve kültürel varlıkları çekim gücüne dönüştürerek turizm pazarından pay elde etmek ve gelişme sürecinde karşılaştıkları darboğazları aşmak için turizmi bir iktisat politikası aracı olarak kabul etmektedirler.

Turizmin olumlu ekonomik, sosyo-kültürel ve çevresel etkilerinin yanında plansız gelişme sonucu ortaya çıkan bir takım olumsuz etkileri de bulunmaktadır. Özellikle destinasyonları ziyaret eden turistler ve onların ihtiyaçlarını karşılamaya çalışan turistik işletmeler doğal ve sosyo-kültürel çevrede bir takım bozulmalara sebep olmaktadırlar. Tahrip olan kaynakların ise tekrar kurtarılması bazen imkânsız hale gelmekte bazen ise uzun süreçler gerektirmektedir.

Turizmin bozulmamış doğal ve kültürel kaynaklara dayanarak gelişmesinin önemini kavrayan ülkeler bir yandan sahip oldukları değerlerin gelecek kuşaklara da aktarılabilmesi, diğer yandan da ekonomik kazanç sağlanmaya devam edilebilmesi için sürdürülebilir turizm politikalarını benimsemektedirler. Sürdürülebilir gelişme ile doğal kaynakların bilinçli kullanımının yaygınlaştırılması sayesinde turizm sektörünün yapısından kaynaklanan olumsuz etkilerin azaltılması mümkün olmaktadır. Böylece turizmden sağlanacak ekonomik, sosyal ve çevresel fayda düzeyi artırlabilmektedir. Bu nedenle; son yıllarda dünyada sürdürülebilirlik kavramı giderek önem kazanmaktadır.

Sürdürülebilir turizm; ekonomik gelişme, çevresel kaynakların korunması ve yerel halkın sosyal fayda elde etmesi bakımından bir denge unsuru olarak kabul edilmektedir. Bu doğrultuda; sürdürülebilir turizm politikaları ve planları ile birlikte günümüzde elde edilen faydanın gelecekte de devam etmesi amaçlanmaktadır. Özellikle gelişmekte olan ülkeler, sürdürülebilir kalkınmanın sağlanması için birtakım ilkeler benimseyerek kaynaklarını korumakta, benimsedikleri bu ilkeleri ulusal politikalara ve planlara dahil etmektedirler.

Destinasyonlar ekonomik kalkınma aracı olarak turizmden yarar sağlamayı rasyonel bir davranış olarak görmekte ve bunu sürdürülebilirlik yaklaşımı ile desteklemeye çalışmaktadırlar. Sürdürülebilir turizm sayesinde destinasyonlar çevresel kaynaklarını korumakta, sosyal fayda elde etmekte ve ekonomik 
kalkınma sağlamaktadırlar. Bu faydaların artırılabilmesi için turistik destinasyonda özellikli ürünlerin oluşturulması öncelikli hedef olarak belirlenmektedir. Birleşik bir turistik ürün olarak destinasyonu oluşturan faktörlerin turizm pazarında rekabet gücü oluşturabilmesi için sahip olunan kaynakların koruma-kullanma dengesi gözetilerek ekonomik girdi haline dönüştürülmesi gerekmektedir. Destinasyonun sahip olduğu kaynaklar ne kadar fazla ise, turistik ürün çeşitlendirmesi yapma imkanı o kadar fazla olacak, bu şekilde ortaya çıkan turistik ürün sayısı da artacaktır. Özellikle destinasyonların sahip olduğu doğal kaynaklar, iklim, yerel doku, mimari yapı önemli çekicilikler olarak kabul edilmektedir. Turizm çeşitlendirmesinde bu unsurların göz önünde bulundurulması ve değerlendirilmesi destinasyonun yaşam döneminin uzamasına neden olacaktır.

$\mathrm{Bu}$ araştırmanın amacı, son yıllarda Türkiye'nin en popüler destinasyonlarından biri haline gelen Alaçatı'nın sahip olduğu doğal ve sosyo-kültürel varlıklarının gelecek kuşaklara aktarılması amacı ile yapılması gereken planlara ve politikalara rehberlik etmektir. Bu amaç doğrultusunda; çalışmada önce sürdürülebilir turizm kavramı açıklanmıştır. Daha sonra araştırma yöntemi açıklanarak Alaçatı'nın sürdürülebilirliği ile ilgili 15 kişi ile yapılan görüşme bulgularına yer verilmiştir.

\section{Sürdürülebilir Turizm}

Sürdürülebilirlik kavramının önemi Birleşmiş Milletler tarafından 1972 yılında Stockholm’de düzenlenen "İnsanın Çevresi" (UNCHE: United Nations Conference on the Human Environment) konulu konferansa kadar anlaşılamamıştır. Daha sonra kavram üzerine olan çalışmalar yoğunlaştırılmış ve 1987 yılında yayınlanan Brundtland Raporu ile birlikte sürdürülebilirlik kavramı tekrar şekillenmiştir. Brundtland raporuna göre; sürdürülebilirlik günümüzün ihtiyaçlarının, gelecek nesillerin kendi ihtiyaçlarını karşılama kabiliyetlerine zarar vermeden karşılanması olarak ifade edilmiştir (Brundtland, 1987). Sürdürülebilirlik kavramının başarıya ulaşması için kalkınma kavramının da tanımlanması gerekmektedir. En yalın ifade ile "sürdürülebilir kalkınma"; insan ile doğa arasında denge kurarak doğal kaynakları tüketmeden, gelecek nesillerin ihtiyaçlarının karşılanmasına ve kalkınmasına imkân verecek şekilde bugünün ve geleceğin yaşamını ve kalkınmasını programlama anlamını taşımaktadır (Yüksek, 2010). Burada amaç, doğal sermaye stokunda bir azalma olmaksızın gelecek nesillerin de bugünkü nesiller gibi aynı refah düzeyinde yaşamalarını sağlamaktır (Çetin, 2006). Sürdürülebilir kalkınma; koruma ve kalkınma kavramlarını bünyesinde barındırmakta ve eş zamanlı ele almaktadır. Sürdürülebilir kalkınma kavramında; bir taraftan kalkınma sağlanır iken diğer taraftan da korumanın sağlanmasına odaklanılmakta, bu nedenle hem doğal kaynakların hem de insan kaynaklarının kalitesini iyileştirmeye ve bunlardan uzun süreli yararlanılmasını sağlamaya çalışan bir yaklaşım olarak benimsenmektedir (Kaya, 1997).

Sürdürülebilir turizm olgusu sürdürülebilir kalkınmaya dayanmaktadır ( Hardy ve Beeton, 2009). Kalkınmanın temelinde yer alan çevre bilinci ve çevre konusundaki değerlendirmeler turizm sektöründe ayrı bir öneme sahiptir. Sürdürülebilir turizm ekonomik gelişme, çevresel kaynakların korunması, yerel halkin ve turistlerin tatmini konusunda bir denge unsuru kabul edilmektedir (Hunter, 2002). Turist, yerel halk, işletmeler, bölgesel çekicilikler ve doğal çevre arasında karmaşık, birbirini etkileyen, ortak yaşamla oluşan bir ilişki bulunmaktadır (Edgell, 2006). Sürdürülebilir turizmin en belirgin özelliği hem yerel halkın hem de ziyaretçilerin ihtiyaçlarının karşılanması ve birer ekonomik kaynak olarak kullanılan turistik çekiciliklerin zenginleştirilip korunmasıdır (Edgell, 2006).

Sürdürülebilir turizm, doğal kaynakların korunarak kalkınmanın gerçekleşmesini ve turizm gelişiminin planlı temellere dayandırılmasını ön koşul olarak kabul etmektedir. Böylece doğal ve kültürel varlıklar korunurken bölgede ekonomik ve sosyal gelişim de sağlanmaktadır (Rebollo ve Baidal, 2003). Turizm açısından verimli arazilerin planlanarak kullanımı ile turistik destinasyonlarda sürdürülebilir turizm yönetimi uygulamaları hayata geçirilebilmektedir Bu uygulamalar ile uzun dönemli ekonomik gelişim ve fayda ortaya çıkmaktadır (Mazilu, 2010). Çünkü turistik destinasyonlardaki en büyük sorunlardan biri; turizm paydaşlarının kısa dönemli çıkarlar için kaynakları plansızca kullanıp tahrip etmelerinden kaynaklanmaktadır (Buhalis, 2000). Sürdürülebilir turizm ile birlikte turistik destinasyonlarda meydana gelen ekonomik canlılık iş çeşitliliğini arttıracak, dolayısıyla yerel halkın çalışma şartlarında ve gelirlerinde iyileşmeler meydana gelecektir (Baker ve Cameron, 2008). Böylece, yerel halkın turizmden fayda elde etmesi ile birlikte turizme bakış açısı olumlu yönde etkilenecektir. Bununla birlikte ülkenin ve destinasyonun imajının güçlenmesine katkı sağlanacak, ödemeler dengesi olumlu yönde etkilenecek, turizmin yarattığı çarpan etkisi sayesinde ulusal ekonomik sektörlerin yapısı çeşitlenecektir (Mazilu, 2012).

Sürdürülebilir turizm içinde birçok boyut ve bu boyutları destekleyen aktörler bulunmaktadır (Günlü, 2014). Bu aktörler arasında yer alan turistlerin memnuniyeti planlı turizm gelişimine bağlı olarak artış gösterecek, böylece gelir ve harcama düzeyi yüksek turistler destinasyonu daha fazla tercih etmeye başlayacaktır (Buhalis, 1999). Sürdürülebilir destinasyon yönetiminin başarı unsurlarından olan tarihi 
mirasın korunması, otantik kültüre sahip çıkılması, yerel geleneklerin ve değerlerin korunması sayesinde ise kültürel zenginlik sağlanacak, destinasyona yönelik talep artacak ve yerel halkın refah düzeyi artacaktır (Mazilu, 2012).

\section{Araştırmanın Amacı}

Araştırmanın amacı; son 15 yıldır süratle gelişen ve turistik çekim merkezi haline gelen Alaçatı'nın sürdürülebilir turizm açısından doğal ve sosyo-kültürel varlıklarında meydana gelen değişimin irdelenmesi olarak belirlenmiştir.

Bu kapsamda geliştirilen araştırma soruları şu şekildedir:

1. Türkiye'nin en önemli turistik destinasyonlarından biri olan Alaçatı'nın doğal ve kültürel varlıklara dayanan turistik ürünleri nelerdir?

2. Alaçatı'nın sahip olduğu turistik ürünlerin sürdürülebilirliği için yapılması gerekenler nelerdir?

\section{Metodoloji}

$\mathrm{Bu}$ çalışma, sürdürülebilir turizm kapsamında Alaçatı turizminin değerlendirilmesine ilişkin zengin ve derinlemesine betimlemeler gerektirdiğinden nitel bir araştırma olarak tasarlanmış ve uygulanmıştır. Nitel araştırma yöntemlerinden görüşme tekniği ile veriler toplanmıştır. Özellikle bölgeye yönelik çevresel faktörlerin ve kısıtların ürettiği özgün bir bağlam içinde faaliyet gösteren işletmelerin ve destinasyonun sürdürülebilirliğinin hangi unsurlardan etkileneceği yönündeki dinamiklerin belirlenmesine yönelik derinden ve özgün yanıtlar belirlenmiştir.

Araştırma için Alaçatı'da bulunan, turizm faaliyetlerinde karar veren ve söz sahibi olan kamu sektörü, özel sektör ve sivil toplum örgütleri yöneticileri ile temsilcilerinden oluşan 17 kişi ile görüşme talebinde bulunulmuştur. Görüşme isteği yönlendirilen iki uzmandan işlerinin yoğunluğu nedeni ile randevu alınamamış, geri kalan 15 kişi ile uygun gördükleri zaman diliminde randevu alınarak görüşmeler yapılmıştır. Görüşmeler 2 Kasım 2014 - 18 Ocak 2015 tarihleri arasında yapılmıştır. Görüşme yapılan kişilerin işletme sahibi olmaları ve yoğun olmaları nedeni ile randevu alınması sırasında zorluklarla karşılaşılmıştır. Araştırmada yarı yapılandırılmış görüşme tekniği tercih edilmiş ve bu teknik ile veriler toplanmıştır. Yarı yapılandırılmış görüşmede araştırmacı yönelteceği soruları önceden hazırlamaktadır. ). Görüşme formu araştırma problemi ile ilgili tüm boyutların ve soruların kapsamını güvence altına almak için geliştirilmiş bir yöntemdir (Yıldırım ve Şimşek, 2013). Sorular yöneltilirken araştırmacı yeni sorular sorma gereği duyduğu taktirde onları da görüşleri alınan kişilere yöneltmektedir (Mil, 2007).

Araştırmada uzmanlar ile yapılan görüşmeler 40 ile 90 dakika arasında sürmüştür. Yönlendirilen sorular, araştırma konusu ve amacı ile doğrudan ilgilidir. Araştırmadaki sorular literatür kaynaklarının taranması ve konuya yönelik yapılan araştırmalar, tartışmalardan sonra zengin bir bilgi birikimi ile hazırlanmıştır. Araştırma soruları (EK 1) ve mülakat yapılan kişiler (EK 2) eklerde belirtilmiştir.

Veri analizi kısmında, görüşmeler sonunda elde edilen verilere içerik analizi uygulanmıştır. İçerik analizinde temel amaç, toplanan verileri açıklayabilecek kavramlara ve ilişkilere ulaşmaktır. Toplanan veriler önce kavramsallaştırılır, daha sonra ortaya çıkan kavramlar mantıklı bir biçimde düzenlenir ve buna göre veriyi açıklayan temalar saptanır (Yıldırım ve Şimşek, 2013).

Araştırmanın analiz aşamasında öncelikle görüşme kayıtları yazılı hale getirilmiş, her görüşün kaç kez tekrarlandığı ve bu görüşlerin yüzde dağılımları belirtilmiştir. Son aşamada ise her soru için görüşme yapılan uzmanların fikir ve görüşleri yorumlanarak rapor haline getirilmiştir.

Araştırmanın geçerliği için ses kayıt cihazına kaydedilen mülakat söylemlerinin bilgisayar ortamında yazılı hale getirilmiştir, bunun sonucunda 184 sayfalık tam veri metni oluşturulmuştur. Benzer veriler gruplandırılmış ve kategoriler altında bir araya getirerek ana temaların belirlenmesi sağlanmıştır. Araştırmaya katkı sağlayan bağımsız bir uzman araştırmacı tarafından da veri dosyalarının ayrı ayrı okunarak benzer veriler tekrar gruplandırılıp, kategoriler oluşturulmuş ve ortak ana temalar belirlenmiştir. Farklı uzmanların metinlerde saptadıkları temalar arasında yüksek oranda benzerlik görülmüştür. Bu bulgular araştırmanın güvenilirliğine yüksek oranda katkı sağlamaktadır.

\section{Bulgular}

\section{Bulgu 1:}

Görüşmeler esnasında mülakat yapılan kişilere son yıllarda Alaçatı turizminde gözlemledikleri gelişim süreci sorulmuş ve bu süreci değerlendirmeleri istenmiştir. Katılımcıların tamamı Alaçatı turizminin gelişim sürecinin 2000'li yıllara dayandığını ve son 15 yılda Alaçatı'da gerek turizm talebinde gerek ise turizm yatırımlarında büyük bir artış olduğunu gözlemlediklerini belirtmişlerdir. Özellikle son 5 yılda 
daha da hızlanan bu gelişme ile birlikte yaz aylarında aşırı kalabalık bir turist kitlesi ile karşı karşıya kalındığı belirtilmiştir.

Tablo 1. Alaçatı Destinasyonunun Gelişim Süreci

\begin{tabular}{|c|c|c|c|c|c|c|c|c|c|c|c|c|c|c|c|c|c|}
\hline & 1 & 2 & 3 & 4 & 5 & 6 & 7 & 8 & 9 & 10 & 11 & 12 & 13 & 14 & 15 & $*$ & $\begin{array}{l}\text { Oran } \\
(\%)\end{array}$ \\
\hline Turist Sayısında Artış & & $\mathrm{X}$ & $\mathrm{X}$ & $\mathrm{X}$ & $\mathrm{X}$ & $\mathrm{X}$ & & $\mathrm{X}$ & & $X$ & $\mathrm{X}$ & $\mathrm{X}$ & $\mathrm{X}$ & & & 10 & 66,6 \\
\hline Yatırımda Artış & $\mathrm{x}$ & $\mathrm{x}$ & $\mathrm{x}$ & $\mathrm{x}$ & & $\mathrm{x}$ & $\mathrm{x}$ & $\mathrm{x}$ & & $\mathrm{x}$ & $\mathrm{x}$ & $\mathrm{x}$ & $\mathrm{x}$ & & $\mathrm{x}$ & 12 & 80 \\
\hline Tanitim & & $\mathrm{x}$ & & & $\mathrm{x}$ & & & $\mathrm{x}$ & $\mathrm{x}$ & $\mathrm{X}$ & $\mathrm{x}$ & & $\mathrm{x}$ & $\mathrm{x}$ & & 8 & 53,3 \\
\hline Mimari yap1 & $\mathrm{x}$ & & & & & & $\mathrm{x}$ & & & & & & $\mathrm{x}$ & $\mathrm{x}$ & $\mathrm{x}$ & 5 & 33,3 \\
\hline Hızlı Gelişim & & & & $\mathrm{X}$ & & & $\mathrm{X}$ & $\mathrm{X}$ & & & $\mathrm{X}$ & $\mathrm{x}$ & & $\mathrm{x}$ & & 6 & 37,5 \\
\hline
\end{tabular}

*Kodların katılımcılar tarafindan tekrarlanma sayısı

Turistik işletme sayısında (küçük oteller, eğlence mekanları, yiyecek-içecek işletmeleri) ve turist sayısında meydana gelen artış dikkat çekici şekilde fark edilmektedir.

Görüşme 1 “Özellikle 2000'li yıllar itibari ile Alaçatı'da turistik işletme sayısında önemli bir atış meydana gelmiştir."

Gelişimin bu denli hızlı olmasının sebebi Alaçatı'nın sahip olduğu doğal ve kültürel kaynakların son 15 yılda yatırımcılar ve turistler tarafından fark edilmesidir. Bununla birlikte; Kuşadası ve Marmaris gibi önemli çekim merkezlerinde meydana gelen olumsuz değişimin farkında olan yatırımcılar ve yerel yönetim benzer hataların Alaçatı'da tekrarlanmasını önlemek amacı ile bir takım tedbirleri almalıdırlar.

Alaçatı'nın bugün bu kadar popüler hale gelmesinin en büyük nedenlerinden biri olarak mimari yapısının korunmuş olmasını belirten katılımcılar, yapılan tanıtım ve kaliteli yatırımların da Alaçatı turizminin gelişim sürecine olumlu katkı sağladığını düşünmektedirler.

Alaçatı'nın denizden uzak, çok yeşil olmayan bir yerleşim yeri olmasına rağmen bu kadar talep gören bir destinasyona dönüşme sebepleri arasında, vizyon sahibi yatırımcıların bölgede yatırım ve tanıtım yapmasının, eski taş evlerin restore edilerek küçük otellere dönüştürülmesinin destinasyon imajının oluşturulmasını sağladığını ve Alaçatı'yı bir marka haline getirdiğini ifade eden katılımcılar bir diğer önemli husus olarak Sivil Toplum Kuruluşları öncülüğünde Alaçatı'nın sit alanına dönüştürüldügünü belirtmektedirler. Katılımcıların vurguladıkları en önemli nokta; Alaçatı turizminin gelişim sürecinde bu beldenin sit alanına dönüşmesi yapılaşmanın ve betonlaşmanın bir nevi önüne geçilmesini sağladığı yönündedir.

Görüşme 11 “Alaçatı'nın mimari dokusu, tarihi ve sosyal dokusu, doğal dokusu korunarak turizm talebinin destinasyona çekilmesi en önemli hedeflerimizden bir tanesidir."

Sürdürülebilir turizmin en önemli hedeflerinden bir tanesi doğal ve kültürel yapıyı bozmadan, turizmin gelişmesi ile birlikte ortaya çıkacak olumsuzlukların en aza indirilmesi ve dengeli bir gelişim sağlanmasıdır. Görüşme yapılan katılımcıların genelinde bu bilincin olduğu saptanmıştır. Alaçatı'da turizm gelişirken beldenin sahip olduğu değerlerin turistik talebi çektiği ve ancak bu değerlerin korunduğu takdirde planlı bir gelişim sağlanacağı ortadadır. Bu görüşlerin yanı sıra bazı katılımcılar ise Alaçatı'da sonradan yapılan taş evlerin doğallığı bozduğu yönünde görüş bildirmişlerdir.

Görüşme 15 “Alaçatı'da sonradan yaplan taş evler, otantikliği bozmaktadır. Yerel yönetimin rant kaygısını bir kenara bırakıp daha güçlü bir kontrol mekanizması ile yapılaşmanın önüne geçmesi gerekmektedir."

Mimari yapıya uymayan, sonradan aslına uygun olarak yapılmayan gerek ikinci konutlar gerek ise turizm işletmeleri Alaçatı'nın sahip olduğu otantik yapının bozulmasına neden olmaktadır.

\section{Bulgu 2:}

Destinasyonlardaki turizm sistemi içinde bulunan ve turistleri destinasyonu ziyaret etmeye teşvik eden bütün değerler turistik çekicilikler olarak adlandırılabilmektedir. Destinasyonların sahip olduğu çekicilikleri sekiz grupta sınıflandırmak mümkündür. $\mathrm{Bu}$ çekicilikler; doğal çekicilikler, tarihi çekicilikler, kültürel çekicilikler, konulu parklar, özel dönemsel çekicilikler ve etkinlikler, eğitim amaçlı çekicilikler, rekreasyon ve diğer çekicilikler şeklinde sıralanabilir (Aktaş, 2007). Bu araştırmada, Alaçatı'nın turistik çekicilikleri irdelenmiş ve cevaplar aşağıda bulunan Tablo 2'de gösterilmiştir. Buna göre; katılımcılarım tamamı Alaçatı'nın sahip olduğu en büyük çekiciliğin sörf turizmi (uygun rüzgar, 
sörf plajları) olduğunu düşünmektedirler. Alaçatı'nın yerli ve yabancı turistler tarafından tanınması ve talep görmesinin en büyük sebeplerinden birinin sörf turizmi olduğu düşünülmektedir.

Görüşme 2 “Alaçatı rüzgar sörfü adına güzel esen yan rüzgarl, düz ve emniyetli su derinliği, uygun pratik ve eğitim alanları ile yerli ve yabancı turistlerin dikkatini çekmektedir."

Tablo 2. Alaçatı Destinasyonundaki Turistik Ürün ve Çekicilikler

\begin{tabular}{|c|c|c|c|c|c|c|c|c|c|c|c|c|c|c|c|c|c|}
\hline & 1 & 2 & 3 & 4 & 5 & 6 & 7 & 8 & 9 & 10 & 11 & 12 & 13 & 14 & 15 & $*$ & $\begin{array}{l}\text { Oran } \\
(\%)\end{array}$ \\
\hline Gastronomi & $\mathrm{x}$ & & & $\mathrm{X}$ & $\mathrm{X}$ & $\mathrm{X}$ & $\mathrm{X}$ & $\mathrm{x}$ & $\mathrm{X}$ & $\mathrm{x}$ & $X$ & $\mathrm{x}$ & $\mathrm{x}$ & $\mathrm{x}$ & $\mathrm{x}$ & 13 & 86,6 \\
\hline Mimari yapı & $\mathrm{x}$ & $\mathrm{x}$ & $\mathrm{x}$ & $\mathrm{x}$ & $\mathrm{x}$ & $\mathrm{x}$ & $\mathrm{x}$ & $\mathrm{x}$ & $X$ & $\mathrm{x}$ & $X$ & $\mathrm{x}$ & $\mathrm{x}$ & $\mathrm{X}$ & & 14 & 93,3 \\
\hline $\begin{array}{l}\text { Sörf } \\
\text { imkanları: } \\
\text { Rüzgar ve } \\
\text { plajlar }\end{array}$ & $\mathrm{x}$ & $\mathrm{x}$ & $\mathrm{x}$ & $\mathrm{x}$ & $\mathrm{x}$ & $\mathrm{x}$ & $\mathrm{x}$ & $\mathrm{x}$ & $\mathrm{X}$ & $\mathrm{x}$ & $\mathrm{X}$ & $\mathrm{x}$ & $\mathrm{x}$ & $\mathrm{X}$ & $\mathrm{X}$ & 15 & 100 \\
\hline $\begin{array}{l}\text { Eğlence } \\
\text { mekanları }\end{array}$ & & $\mathrm{x}$ & $\mathrm{x}$ & & $\mathrm{x}$ & & $\mathrm{x}$ & & & & & $\mathrm{x}$ & $\mathrm{x}$ & $\mathrm{x}$ & & 7 & 46 \\
\hline $\begin{array}{l}\text { Konaklama } \\
\text { işletmeleri }\end{array}$ & & $\mathrm{x}$ & & & & & & & & $\mathrm{x}$ & $\mathrm{X}$ & & $\mathrm{x}$ & $\mathrm{X}$ & $\mathrm{X}$ & 6 & 40 \\
\hline $\begin{array}{l}\text { Kolay ulaşım } \\
\text { imkanları }\end{array}$ & & $\mathrm{x}$ & & & & & $\mathrm{x}$ & & & & $\mathrm{X}$ & & & & & 3 & 20 \\
\hline $\begin{array}{l}\text { Alaçat1 } \\
\text { Marina }\end{array}$ & & $\mathrm{X}$ & X & $\mathrm{X}$ & & $\mathrm{X}$ & & & & & $\mathrm{X}$ & & & & & 5 & 33,3 \\
\hline $\begin{array}{l}\text { Yerel doku } \\
\text { (otantik doku) }\end{array}$ & & & $\mathrm{x}$ & & & & $\mathrm{x}$ & & $\mathrm{x}$ & $\mathrm{x}$ & & $\mathrm{x}$ & & $\mathrm{x}$ & & 6 & 40 \\
\hline $\begin{array}{l}\text { Ulusal ve } \\
\text { uluslararası } \\
\text { festivaller }\end{array}$ & & & & & & $\mathrm{X}$ & $\mathrm{X}$ & $X$ & & $\mathrm{X}$ & & & $\mathrm{x}$ & $\mathrm{X}$ & & 6 & 40 \\
\hline Plajlar & $\mathrm{x}$ & & & & & & & & $\mathrm{X}$ & $\mathrm{x}$ & & $\mathrm{x}$ & $\mathrm{x}$ & & & 5 & 33,3 \\
\hline Yerel halk & & & & & & & & & & $\mathrm{x}$ & & $\mathrm{x}$ & $\mathrm{x}$ & & & 3 & 20 \\
\hline $\begin{array}{l}\text { Servis ve } \\
\text { hizmet kalitesi }\end{array}$ & & $\mathrm{X}$ & & & & & & & & $\mathrm{X}$ & $\mathrm{X}$ & & & & & 3 & 20 \\
\hline Şarap bağları & & & & $\mathrm{X}$ & & & & $\mathrm{X}$ & & & & & & & & 2 & 13,3 \\
\hline
\end{tabular}

*Kodların katılımcılar tarafindan tekrarlanma sayısı

Görüşme 3 “Alaçatı'nın yazılı ve görsel medyada sıklıkla yer alması, doğal mimarisinin korunması turistleri bu destinasyona çekmektedir."

Görüşme yapılan 15 katılımcının \%93'ü turistleri Alaçatı'ya çeken nedenlerden bir tanesinin destinasyonun sahip olduğu mimari yapı ve restore edilen taş evler olduğunu düşünmektedirler.

Görüşme 14 “Alaçatı'nın gelişirken mimari yapısının korunarak gelişimi, taş evlerin korunması beldenin markalaşmasına ve farklılık kazanmasına neden olmuştur." 
Yapılan görüşmelerde bazı katılımcılar Alaçatı’nın mimari yapısının aslına uygun olarak korunduğunu düşünürken bazı katılımcılar ise sonradan yapılan taş evlerin Alaçatı'nın otantik yapısını bozacağını savunmaktadirlar.

Görüşme 12 "Turistleri destinasyona çeken en önemli nedenler arasında otantik yapısl ve mimari dokunun korunması gelmektedir. Fakat sonradan yapılan taş evler sayesinde Alaçatı'nın otantik yapısının bozulacă̆ını düşünmekteyim."

Katılımcıların \%40’1 Alaçatı'nın sahip olduğu otantik yapının turistleri destinasyona çektiğini düşünmektedir. Otantik yapının bozulmasının ya da sonradan yapılan taş evler ile yapaylaşmasının gelecek zamanlarda talebin düşmesine sebep olacağı düşünülmektedir.

Görüşme 5 “Alaçatı'nın en önemli çekiciliği destinasyonun sörf turizmi açısından bir cazibe merkezi olmasıdır. Ayrıca yerel yönetimin mimari ve tarihi doku üzerinde gösterdiği hassasiyet sayesinde yerel doku korunmuş bu durumda turistlerin destinasyona rağbet göstermesini sağlamıştır. Eğlence mekânlarl, yerel ve amatör restoranların değişik tatları turistlere sunması ile de Alaçatı'yı gastronomi merkezi haline gelmiştir."

Görüşme 11 “Alaçatı'yı çekici kılan özellikler arasında çok sayıda ve birbirinden güzel küçük otellerin bu destinasyonda toplanmasl ve kaliteli hizmet vermesidir."

Oteller, konaklama tesisleri ve eğlence mekânları turistik ürünün önemli bir alt bileşeni olarak düşünülmektedir (Usta, 2009). Katılımcıların \%86,6's1 destinasyonda hizmet veren restoranların, \%46's1 ise küçük otellerin cazibe yarattığını düşünmektedirler. Destinasyonda düzenlenen ulusal ve uluslararası festivallerin önemi ise katılımcıların \%40’ı tarafından vurgulanmıştır.

\section{Bulgu 3:}

Alaçatı'ya yönelik talebin yapısal özellikleri irdelendiğinde ise özellikle yerli turist sayısının destinasyonu büyük oranda tercih ettiği dikkat çekmektedir.

Tablo 3. Alaçatı Destinasyonunun Talep Yapısı

\begin{tabular}{|l|c|c|c|c|c|c|c|c|c|c|c|c|c|c|c|c|c|}
\hline & 1 & 2 & 3 & 4 & 5 & 6 & 7 & 8 & 9 & 10 & 11 & 12 & 13 & 14 & 15 & $*$ & $\begin{array}{c}\text { Oran } \\
(\%)\end{array}$ \\
\hline Yerli Turist & $\mathrm{x}$ & $\mathrm{x}$ & $\mathrm{x}$ & $\mathrm{x}$ & $\mathrm{x}$ & $\mathrm{x}$ & $\mathrm{x}$ & $\mathrm{x}$ & $\mathrm{x}$ & $\mathrm{x}$ & $\mathrm{x}$ & $\mathrm{x}$ & $\mathrm{x}$ & $\mathrm{x}$ & $\mathrm{x}$ & 15 & 100 \\
\hline $\begin{array}{l}\text { Az Sayida Yabanc1 } \\
\text { Turist }\end{array}$ & $\mathrm{x}$ & & & $\mathrm{x}$ & $\mathrm{x}$ & & $\mathrm{x}$ & $\mathrm{x}$ & $\mathrm{x}$ & & & & & $\mathrm{x}$ & 7 & 46,6 \\
\hline
\end{tabular}

*Kodların katılımcılar tarafindan tekrarlanma sayısı

Görüşme 4 "Alaçatı ilk başlarda orta yaşlı ve emekli insanların dinlenebileceği bir belde iken bu kesim şu anda yaz sezonu çok kalabalık olduğu için yazın gelmeyi tercih etmiyor."

Katılımcıların yaptığı genel değerlendirmelere göre Alaçatı'ya gelen turistleri eğlenme ve dinlenme amaçlı olarak ikiye ayırmak mümkündür. Nisan, Mayıs, Haziran ve Eylül, Ekim, Kasım aylarında dinlenme amaçlı, yaş ortalaması biraz daha yüksek turist kitlesi ile karşılaştıklarını Haziran, Temmuz, Ağustos aylarında ise yaş ortalaması daha düşük turist kitlesi ile karşılaştıklarını vurgulamışlardır.

Görüşme 3 “Gençler, eğlence hayatı için Alaçatı'ya gelirken orta yaşlı turistler Alaçatı'yı otantik yapisindan dolayı tercih ediyor."

Özellikle yaz aylarında yaş ortalaması düşük turist kitlesi Alaçatı'yı eğlence mekânları ve plajları için tercih ederken yaş ortalaması yüksek turist kitlesinin Alaçatı'yı otantik yapısı için tercih ettikleri belirtilmiştir.

Görüşme 2 "Yabancı turistlerin Alaçatı'yı tercih etme nedenleri arasında yaygın tanıtım ve sörf turizmi gelmektedir."

Görüşme 5 "Yabancı turist sayısında artışın sebebi; Alaçatı Turizm Derneği ve bir takım küçük otel işletmelerinin yurt dışında fuarlara katılmasından kaynaklanmaktadır."

Yabancı turist sayısında son yıllarda artış olduğu vurgulanmıştır. Bu artışın sebepleri arasında; sörf turizmi, Alaçatı'nın yurt dişı fuarlarında tanıtımının yapılması, sosyal medya araçları vasıtasıyla duyurulması, Sakız adasında yaşayanların Alaçatı pazarına gelmesi, Selçuk ve Efes'i ziyaret edecek turistlerin Alaçatı'da konaklamayı tercih etmesi ve Alaçatı'da kurulan derneklerin payı sayılabilir.

Görüşme 14 “Destinasyona az sayıda yabancı turist gelmesinin sebebi, özellikle Çeşme ve Alaçatı'da bulunan konaklama işletmelerinin oda-kahvaltı sistemi ile çalışmasından kaynaklanmaktadır."

Katılımcılar destinasyonu ziyaret eden yabancı turist sayısının artması için; yurt dışında Alaçatı'nın tanıtımının daha fazla yapılması, oda-kahvaltı sistemi yerine tam pansiyon sistemine geçilmesi, alternatif 
turizm çeşitlerinin arttırılması önerilerinde bulunmuştur. Fakat destinasyonda tam pansiyon sistemine geçiş genel anlamda olumsuz sonuçlar doğuracaktır. Destinasyondaki yiyecek-içecek işletmeleri bu durumdan olumsuz olarak etkileneceklerdir. Alaçatı tam pansiyon sistemi için uygun bir destinasyon değildir.

Görüşme 11 "Eskiden yaş ortalaması daha yüksek turist kitlesi Alaçatı'yı ziyaret ederken son dönemlerde yaş ortalaması daha düşük turist kitlesi ile karşılaşılmaktadır."

Alaçatı'yı ziyaret eden turistik talebin yaş ortalamasının, destinasyonun popüler olması ve eğlence mekânlarının sayısının artması ile birlikte düştüğü gözlemlenmişstir. Ayrıca turistik talebin yapısında sezonluk farklılıklar da gözlemlenmektedir. Yüksek sezon dışında yaş ortalaması ve gelir seviyesi yüksek yerli turistler destinasyonu ziyaret ederken, yüksek sezonda yaş ortalaması düşük özellikle sörf turizmi ve eğlence mekânları için yerli turistlerin destinasyonu ziyaret ettiği düşünülmektedir. Konaklama ve yiyecek-içecek işletmelerinde fiyatların yüksek olması destinasyonun gelir seviyesi yüksek yerli turistler tarafından tercih edilmesine sebep olduğu belirtilmiştir.

\section{Bulgu 4:}

Turizmin geliştiği destinasyonlarda sosyal, kültürel ve ekonomik yapıda olumlu ve olumsuz etkilerle karşılaşılmaktadır (WTO, 1993). Alaçatı destinasyonunun sosyo-kültürel ve ekonomik yapısını etkileyen unsurlar aşağıda bulunan Tablo 4'de gösterilmiştir.

Tablo 4. Alaçatı Destinasyonunun Sosyo-Kültürel ve Ekonomik Yapısı

\begin{tabular}{|c|c|c|c|c|c|c|c|c|c|c|c|c|c|c|c|c|c|}
\hline & 1 & 2 & 3 & 4 & 5 & 6 & 7 & 8 & 9 & 10 & 11 & 12 & 13 & 14 & 15 & $*$ & $\begin{array}{l}\text { Oran } \\
(\%)\end{array}$ \\
\hline Yozlaşma & $\mathrm{x}$ & & & & & & & $\mathrm{x}$ & & $\mathrm{x}$ & & $\mathrm{x}$ & & & & 4 & 26,6 \\
\hline $\begin{array}{l}\text { Gayrimenkul fiyatlarında } \\
\text { artış }\end{array}$ & $\mathrm{x}$ & $\mathrm{x}$ & $\mathrm{x}$ & $\mathrm{x}$ & $\mathrm{x}$ & $\mathrm{x}$ & & $\mathrm{x}$ & $\mathrm{x}$ & $\mathrm{x}$ & & & $\mathrm{x}$ & & $\mathrm{x}$ & 11 & 73,3 \\
\hline Geçim kaynağ & & $\mathrm{x}$ & $\mathrm{x}$ & & & $\mathrm{x}$ & $\mathrm{x}$ & $\mathrm{x}$ & $\mathrm{x}$ & & $\mathrm{x}$ & $\mathrm{x}$ & $\mathrm{X}$ & $\mathrm{X}$ & $\mathrm{x}$ & 11 & 73,3 \\
\hline Gelir seviyesinde artış & & $\mathrm{X}$ & $\mathrm{x}$ & $\mathrm{x}$ & & $\mathrm{x}$ & $\mathrm{x}$ & $\mathrm{x}$ & $\mathrm{x}$ & & $\mathrm{X}$ & $\mathrm{x}$ & $\mathrm{x}$ & $\mathrm{X}$ & & 11 & 73,3 \\
\hline Eğitim seviyesinde artış & & & & & $\mathrm{x}$ & & & & & & & & $\mathrm{x}$ & & & 2 & 13,3 \\
\hline İstihdam & & & & & $\mathrm{X}$ & & $\mathrm{x}$ & $\mathrm{x}$ & $\mathrm{x}$ & & $\mathrm{x}$ & $\mathrm{x}$ & $\mathrm{x}$ & $\mathrm{x}$ & & 8 & 53,3 \\
\hline $\begin{array}{l}\text { Kültürel değerlerin } \\
\text { korunması }\end{array}$ & & $\mathrm{x}$ & & & & & & $\mathrm{x}$ & $\mathrm{x}$ & & $\mathrm{x}$ & & & & & 4 & 26,6 \\
\hline Taş evler & & $\mathrm{x}$ & & & & & & $\mathrm{x}$ & $\mathrm{x}$ & & & & & & & 4 & 26,6 \\
\hline Kültürel alışveriş & & $\mathrm{x}$ & & & & & $\mathrm{x}$ & & & $\mathrm{x}$ & $\mathrm{x}$ & & $\mathrm{x}$ & $\mathrm{x}$ & & 6 & 40 \\
\hline
\end{tabular}

*Kodların katılımcılar tarafindan tekrarlanma sayısı.

Görüşme 1 "Sosyo-kültürel yapıda yozlaşma görülmektedir."

Birçok ülkede turistlerin gelmesiyle, değer ve inanç yapısının değiştiği, giyim ve yaşam biçiminde geleneksel kalıplardan uzaklaşıldığı, dilde yabancı sözcük kullanımının arttığı ve kültürel değerlerin özelliklerini yitirdiği gözlemlenmiştir. Bu değişikliklerin ne ölçüde turizmden ne ölçüde sanayileşmeden kaynaklandığını saptamak güçtür. Çözülme durumunda olan toplumsal değişimler karşısında, geleneksel değerlerini yitirmiş olan bir kültür büyük olasılıkla turizmden daha çok etkilenecektir (Doğan, 2004). Turizmin gelişmesi ile birlikte ortaya çıkan olumsuz sosyo-kültürel etkiler arasında değerlerin değişmesi, yaşam biçiminin değişmesi, dilin değişmesi sayılmaktadır. Görüşme yapılan katılımcıların \% 26,6'lık kısmı ekonomik anlamda destinasyonda sağlanan olumlu gelişmelerin sosyo-kültürel anlamda sağlanmadığını belirtmişlerdir. Turizmin gelişmesi ile birlikte yerel halkın yaşam biçimde çok hızlı bir değişim olduğunu, elde edilen sosyal faydanın yetersiz kaldığını ve kültürel yozlaşma ile karşı karşıya kalındığı görüşünü savunmaktadırlar.

Görüşme 2 “Alaçatı’nın kültürel değerlerinin koruması için Alaçatı Koruma Derneği kuruldu.”

Alaçatı'da turizm gelişirken bu destinasyona dişarıdan gelen işletmeciler ve yerel halk "Alaçatı Koruma Derneği’ni kurmuşlardır. Böylece Alaçatı'da kültürel değerlerin yok olmasının önüne geçilmesi 
amaçlanmıştır. Daha sonra dernek adını "Alaçatı Turizm Derneği” olarak değiştirmiş ve dernek üyeleri arasında sadece destinasyonda hizmet veren turizm işletmeleri üye olarak kabul edilmiştir.

Görüşme 2 "Taş evler restore edilmiş, planlı gelişmenin sağlanmasına ve gelir elde edilmesine olanak sağlanmıştır."

Taş evlerin restore edilmesi ile birlikte bu yapılar küçük otellere çevrilmiştir. Alaçatı'nın mimari yapısını koruyarak bir değer kazanması ve fark edilmesi ile birlikte turizmden gelir elde edilmeye başlanmıştır. Turizm sayesinde uzun dönemde kat edilebilecek bir mesafenin daha kısa sürede gerçekleştiği katılımcılar tarafından ifade edilmiştir.

Görüşme 2 "Turizmin beldede gelişmesi ile birlikte karşılıklı kültürel alışveriş meydana gelmiştir."

Yerel halk destinasyon dışından gelen işletme sahipleri sayesinde şehir kültürünü öğrenir iken işletmelerin de yerel halktan bir takım yerel değerleri öğrendiği katılımcılar tarafından ifade edilmiştir. $\mathrm{Bu}$ şekilde karşılıklı sosyal etkileşimin gerçekleştiği ve yerel halk sayesinde unutulan değerlerin hatırlandığı vurgulanmıştır.

Turizmin gelişmesi ile birlikte sosyo-kültürel ve ekonomik yapıda meydana gelen değişimler katılımcılar tarafından şu şekilde belirtilmiştir:

- Yerel halkın, turizmin gelişmesi ile birlikte turizmin önemini kavrayıp çocuklarını turizm dalında eğitime sevk etmesi ,

- Halkın refah seviyesinin artması,

- Halkın turizmden gelir elde etmeye başlaması,

- Yerel halkın açılan turizm işletmelerinde istihdam elde etmeleri,

- $\quad$ Kültürel değerleri korumaya yönelik bir yaklaşım izlenmesi,

- Yapılan festivaller, sanatsal etkinlikler sayesinde halkın vizyonunun gelişmesi ve kültür seviyesinin artmas1,

- $\quad$ Tarım yerine turizmden doğrudan ya da dolaylı olaylı olarak gelir elde etmeye başlanması.

Görüşme 6 "Gayrimenkul fiyatlarında yüksek oranda artış meydana gelmiştir."

Katılımcıların \%73'ü gayrimenkul fiyatlarının arttı̆̆ını ve halkın geçim kaynağının turizmle birlikte değiştiğini belirtmişlerdir.

Görüşme 7 "Yerel halkın geçim kaynă̆ında değişiklikler meydana geldi. Yerel halk tarımla uğraşmak yerine gayrimenkullerini turizm işletmelerine satmaya ya da kiraya vermeye başlad.."

Turizmin yöresel ekonomiler üzerinde olumlu ekonomik etkilerinin yanında olumsuz ekonomik etkileri de bulunmaktadır. Ekonomik faaliyetlerde yapı değişikliği turizmin olumsuz etkilerinden biri olarak kabul edilmektedir. Ekonomik yapılardaki değişim kırsal alanlarda yaşayan insanların mesleklerinde görülmektedir. Özellikle gençlere tarımın dışındaki işler ve yaşam tarzı daha cazip gelmektedir (Avcıkurt, 2007). Alaçatı'da yaşayan yerel halkın, destinasyonda turizmin gelişmesi ile birlikte gelirlerini tarımsal üretim yerine gayrimenkulden elde etmeye başladığı katılımcılar tarafından belirtilmiştir. Özellikle emlak, arazi ve kira bedellerinin çok yüksek olması yerel halkın gelirinin artmasına neden olmaktadır.

Yerel halkın evlerini, evlerinin avlularını kiraya vererek ya da evlerini satarak gelir elde ettikleri belirtilmiştir. Böylece eskiden geçim kaynağı olan tarım, destinasyonda önemini yitirmiştir. Yerel halkın Alaçatı'nın köy dokusu içinden ayrılıp başka yerleşim yerlerine kayması Alaçatı'da suni bir yapının oluşmasına sebep olacağı için otantik yapının bozulacağından endişe edildiği belirtilmiştir. Alaçatı'nın yerel dokusunun bozulmaması için yerel halkın bu doğal doku içinde yaşamasının gerekliliği vurgulanmıştır. Halkın gayrimenkullerini satıp başka bölgelere taşınmasının uzun dönemde olumsuz etkilere sebep olacağı katılımcılar tarafından belirtilmiştir.

Görüşme 12 "Yerel halk açılan turizm işletmelerinde istihdam imkanı bulmuştur. İşletmeler özellikle Alaçatı'da yaşayan personeli çalıştırmayı tercih etmiştir."

\section{Bulgu 5:}

Turizmin istihdam etkisi, talebin bir destinasyonda yoğunluğuna bağlı olarak artmaktadır. Turizmin gelişmesine paralel olarak turistik işletme sayısının artması, işgücü talebini de arttırmaktadır. Özellikle turizmin mevsimlik özelliğinin bir sonucu olarak talebin yoğun olduğu dönemlerde turistik işletmelerde işgücü talebi artmakta mevsim dişında ise iş gücü talebi düşmektedir (Avcıkurt, 2007). Görüşme yapılan katılımcıların \%53'ü Alaçatı'da turizmin gelişmesi ile birlikte yerel halkın turistik işletmelerde iş imkanı bulduğunu, yeni iş kollarının ortaya çıktığını belirtmişlerdir. Özellikle turistik işletmeler tedarikçilerini seçerken yerel işletmeleri tercih ettiklerini ifade etmiş̧lerdir. 
Tablo 5. Yerel Halkın Turizm Gelişimdeki Payı

\begin{tabular}{|l|l|l|l|l|l|l|l|l|l|l|l|l|l|l|l|l|l|}
\hline & 1 & 2 & 3 & 4 & 5 & 6 & 7 & 8 & 9 & 10 & 11 & 12 & 13 & 14 & 15 & $*$ & Oran \\
$(\%)$
\end{tabular}

*Kodların katılımcılar tarafından tekrarlanma sayısı.

Görüşme 1 “Alaçatı'da turizm gelişirken Alaçatı Koruma Derneği kurulmuştu. Bu dernekte yerel halk ve turistik işletmeler bulunmaktaydı fakat daha sonra bu dernek Alaçatı Turizm Derneği'ne dönüştü ve yerel halk artık bu dernekte yer almamaya başladl."

Görüşme 2 "Halkın gelirinin yetersiz olması taş evlerin korunmasına sebep olmuştur."

Alaçatı'nın mimari yapısının korunmasının sebebi; yerel halkın başta evlerini restore ettirecek ya da taş evleri yıkıp yerine yeni ev yapacak gelirlerinin olamaması olarak ifade edilmiştir. Gelir yetersizliği taş dokunun korunmasına sebep olmuştur. Yerel halkın gelir seviyesi arttıkça, sahip olunan otantik dokunun öneminin anlaşıldığ ve daha korumacı davranışların başladığı katılımcılar tarafindan belirtilmiştir.

Görüşme 3 "Yerel halkın turizmin gelişiminde doğrudan bir katkısı olduğunu düşünmemekteyim. Alaçatı' yı bugün bu hale getiren işletmelerin sahipleri dışarıdan gelen insanlardır."

Alaçatı'da turizmin gelişmesinin ve bugün Alaçatı'nın bir marka haline gelmesinin sebebi olarak dışarıdan gelen, geniş vizyonlu işletme sahipleri olduğu belirtilmiştir. Bunun yanı sıra yerel yönetimin bazı bölgeleri sit alanı ilan etmesi, taş evler, yerel doku için katı kurallar koyması da Alaçatı'da turizmin gelişmesine imkan verdiği ifade edilmiştir.

Görüşme 5 "Alaçatı'da turizmin gelişmesinde halkın payı son yıllarda görülmeye başlandı. Başlarda dı̧sarıdan gelen işletme sahipleri turizmin gelişmesini sağladl."

Görüşme 7 "Başlangıç noktasında turizm gelişirken halkın bir payı olduğunu düşünmüyorum. Daha sonra halk turizmin gelir getirdiğini anlayınca turizme katılmaya başlamıştır."

Katılımcılar son iki - üç yıldır yerel halkın turizm faaliyetlerine katıldığını ifade etmişlerdir. Yerel halkın evlerini pansiyon olarak kullanmaya başladıkları ve yerel tatları sundukları restoranlar açmaya başladıkları belirtilmiştir. Bilinçli bir kesimin ise organik tarım yapmaya başlayarak destinasyonda bulunan restoranlara ve küçük otellere ürün vermeye başladıkları ifade edilmiştir.

Katılımcılar başlarda yerel halkın turizm alanında faaliyet gösterecek gelirleri olmadığını belirtmişlerdir. Halkın taş evleri restore ettirecek ve buraların turistik işletmelere dönüştürülecek gelirleri olmadığını bu yüzden de evlerini ve gayrimenkullerini dışarıdan gelen işletmelere satarak veya kiralayarak buraların restore ettirilmesini sağladıklarını ifade etmişlerdir.

2000'li yılların başında halkın turizmin gelişmesine tepki gösterdiğini, ancak turizmin destinasyon üzerinde yarattığı ekonomik ve çevresel olumlu etkileri fark etmeleri ile birlikte giderek tepki göstermemeye hatta yavaş yavaş yerli halkın da turizme katılmaya başladığı belirtilmiştir. Katılımcıların bazıları yerel halkın turizm konusunda eğitilmesi ve bilgilendirilmesi gerektiğini düşünmektedir. Alaçatı'nın sahip olduğu otantik dokunun kaybolmaması için birtakım eğitimler verilmesi gerektiğini düşünmektedirler. Evlerin dışına yapılacak tadilatlar, restorasyonlar hakkında herkesin daha bilinçli olması gerektiğini ifade etmişlerdir.

Görüşme 10 "Yerel halkın turizm gelişirken doğrudan bir katklsı olmamıştır. Evlerini kiraya vererek ya da dışardan gelenlere satarak turistik işletmelerin destinasyonda açılmasını sağlamışlardır."

Görüşmelerde bazı katılımcılar yerel halkın turizm anlamında destinasyona direk bir katkısı olmadığını ancak dolaylı olarak dışarıdan gelen işletmecilere evlerini kiraya vererek ya da satarak turizmin destinasyonda gelişmesini sağladıklarını belirtmişlerdir.

Görüş̧me 11 "Yerel halk güler yüzlü, hoşgörülü ve medeni olduğu için turizm gelişirken bir sorunla karşılaş̧madlk."

Turizmin etkilerinin yerel halk tarafindan yararlı ve doyum verici olarak algılandığında bu etkilere direnme yerine onların benimsendiği görülmektedir. Turizmin etkilerinin benimsenip benimsenmediği ise yerli toplumun tepkilerine yansıdığı görülmektedir (Doğan, 2004).

Yerel halkın açılan turistik işletmelere ve gelen turistlere karşı olumlu tavırları, huzurlu, hoşgörülü, misafirperver, güler yüzlü olmaları, suç oranının az olması, turistleri dolaşırken kimsenin rahatsız etmemesi olumlu davranışlar olarak algılanmaktadır. Katılımcılar tarafından, halkın daha fazla turizmin içinde olmamasının sebebinin ise turizm konusunda eğitimsizliğe bağlanmıştır. Halkın daha fazla 
eğitilmesi gerektiği, böylece ihtiyaç duyulan kalifiye personelin daha rahat bulunabileceği ifade edilmiştir.

Bulgu 6:

Yerel halk turizm gelişim sürecinde gayrimenkullerini kiralayarak, satarak ayrıca açılan turistik işletmelerde çalışarak bu sürecin içinde bulunmuşlardır. Son yıllarda ise turizmin gelişmesi ve talebin artması ile birlikte yerel halkın farkındalı̆̆ının arttı̆̆ı, yerel halkın da turistik işletme açmaya başladı̆̆ını belirtmişlerdir.

Tablo 6. Yerel Dokuda Meydana Gelen Değişiklikler

\begin{tabular}{|c|c|c|c|c|c|c|c|c|c|c|c|c|c|c|c|c|c|}
\hline & 1 & 2 & 3 & 4 & 5 & 6 & 7 & 8 & 9 & 10 & 11 & 12 & 13 & 14 & 15 & $*$ & $\begin{array}{l}\text { Oran } \\
(\%)\end{array}$ \\
\hline Doğallıktan uzaklaşma & $\mathrm{x}$ & & & & & & & & & $\mathrm{x}$ & & $\mathrm{x}$ & & & $\mathrm{x}$ & 4 & 26,6 \\
\hline Otantik Yap1 & & & $\mathrm{x}$ & & & $\mathrm{x}$ & $\mathrm{x}$ & & $\mathrm{x}$ & & & & $\mathrm{x}$ & $\mathrm{x}$ & & 6 & 40 \\
\hline Kültürel Değişim & & $\mathrm{x}$ & & & & & & $\mathrm{x}$ & & & $\mathrm{X}$ & & & & & 3 & 20 \\
\hline İşletme Sayısı & & $\mathrm{x}$ & & & & & & $\mathrm{x}$ & & & $\mathrm{x}$ & & & & & 3 & 20 \\
\hline Restorasyon & & $\mathrm{x}$ & & & $\mathrm{x}$ & $\mathrm{x}$ & & $\mathrm{x}$ & & $\mathrm{x}$ & $\mathrm{x}$ & $\mathrm{x}$ & & $\mathrm{x}$ & & 8 & 53,3 \\
\hline Marka gelişti & & & & $\mathrm{x}$ & $\mathrm{x}$ & & $\mathrm{x}$ & & & & & & $\mathrm{x}$ & $\mathrm{x}$ & & 5 & 33,3 \\
\hline
\end{tabular}

*Kodların katılımcılar tarafından tekrarlanma sayısı.

Görüşme yapılan katılımcıların \%53’ü turizm gelişirken yerel halkın bu gelişim sürecinde bir pay sahibi olmadığını, dışarıdan gelen işletme sahiplerinin Alaçatı'nın bugün bu hale gelmesini sağladığını vurgularken, \%26,6'sı halkın turizmin gelişimindeki payının çok az olduğunu belirtmiştir.

Katılımcıların \%20'si ise Alaçatı'da turizm gelişim süreci içinde yerel halkın payının olduğu düşüncesi içindedir. Bunun sebebi olarak ise turistlere sunulan kültürel değerlerden turistlere gösterilen olumlu davranışlara kadar yerel halkın sürece katkıda bulunduğu düşüncesi içinde olduklarını ifade etmişlerdir. Ayrıca yerel yönetimin yaz aylarının dıșında düzenledikleri festivallerde bu aktivitelerin içinde yerel halkın katılım şartını benimsemeleri yerel halkın turizm gelişimi içine çekilmesini sağladığı, yerel kültürü korumak ve tanıtmak adına yerel halkın bu süreçlerin içinde olduğu belirtmişlerdir.

Görüşme 1 "Yerel doku ruhen ve bedenen doğallığından uzaklaştl."

Sonradan yapılan taş evler ve yerel dokuya uymayan mekânların açılmasına izin verilmesi yerel dokunun doğallığının bozulmasına sebep olduğu katılımcılar tarafından belirtilmiştir.

Görüşme 2 "Dlşarıdan gelen insanların kültürü ile yerel halkın kültürü birbirine adapte oldu."

Turist-yerel halk arasındaki olumlu ilişkiler yerel halkın kendine olan güvenini arttırmakta ve ülke ya da kasabayla övünmelerini sağlamaktadır (Avcıkurt, 2007). Katılımcılar destinasyonda turizmin gelişmesi ile birlikte yerel halkın kültürünün ve dışarıdan gelenlerin kültürünün uyumlaştığını, birbirlerinin kültürleri ve gelenekleri hakkında bilgi sahibi olduklarını, karşılıklı olumlu davranışların geliştiğini belirtmiş̧lerdir.

Görüşme 3 “Gelen turistlerin ilgisini Alaçatı'nın otantik yapısı çekiyor, bu otantik yapıdan gelir elde ediyoruz. Bunun farkında olan işletmeler ve yerel halk bu yapıyı korumaya yönelik işler yapıyor. Bazen işletmeler ve yerel halk tarafindan dokuyu bozmaya yönelik işler yapıldığını görüyoruz ama sonradan pişman olunup düzeltilme çabası içine giriliyor."

Katılımcılar, yerel doku üzerinde olumsuz bir değişim gözlemlemediklerini, yerel dokunun korunması ile birlikte Çeşme'den Alaçatı'ya doğru talebin kaydığını ifade etmişlerdir.

Görüşme 6 "Yerel doku korunuyor ve yerel dokunun korunması Alaçatı'nın bir cazibe kaynağ haline gelmesini sağlamıştır."

Alaçatı'nın restore edilmiş evleri ve konaklama işletmeleri, büyük ölçekli konaklama işletmelerini tercih etmeyen turist kitlesinin destinasyona çekilmesini sağlamıştır. Katılımcılar, evlerin restore edilmesi ile birlikte Alaçatı'da turizmin büyük bir ivme kazandığını ve yerel doku üzerinde olumsuz bir değişikliğe izin verilmediğini belirtmişlerdir. Yerel dokuya uymayan işletmelerin hem diğer işletmeler hem de turistler tarafından dışlandığını dile getirmişlerdir. Sahip olunan otantik dokunun korunmasının Alaçatı'nın tarihi bir dekor olarak kalmasını sağladığı da katılımcılar tarafından ifade edilmiştir.

Katılımcıların \%53,3’ü restore edilen eski taş evlerin sayesinde yerel dokunun korunduğunu düşünmektedir. Özellikle yerel yönetimin mimari yapı üzerindeki hassasiyeti ve desteklediği ulusal ve 
uluslararası festivaller ile birtakım değerlerin kaybolmasının önüne geçtiği katılımcılar tarafından ifade edilmektedir. Restore edilen taş evler ve taş evlerin turizm işletmeleri tarafından kullanılması Alaçatı'nın marka olmasını desteklediği düşünülmektedir.

Görüşme 14 "Alaçatı'da turizmde meydana gelen büyük değişim ve ilerleme sayesinde destinasyon bir kimlik kazandl."

Alaçatı'da taş evlerin restore edilmesi ve farklı mimari konseptler ile konaklama işletmelerine, restoranlara, mağazalara ve hediyelik eşya dükkanlarına dönüştürülmesi Alaçatı’nın farklı bir kimlik kazanmasına neden olmaktadır. Bu değişimin yerel doku üzerindeki gözle görülür olumlu etkileri, rakip destinasyonlardan farklılaşmasına neden olduğu katılımcılar tarafından ifade edilmiştir.

Bununla birlikte bazı katılımcılar ise turizmin hızlı gelişiminin Alaçatı'nın yerel dokusu üzerinde olumsuz etkiler yarattığını düşünmektedirler. Katılımcıların \%26'sı hızlı gelişim karşısında yerel dokunun otantik yapısını yitirdiğini savunmakta ve kültürel yozlaşmaya gidildiğini düşünmektedirler. Meydana gelen bu değişimin sebebi eğlence mekânlarının hızlı artmasına bağlanmaktadır. Destinasyonda yoğun sezonda çok fazla gürültü kirliği olmasının Alaçatı'daki yerel dokuya uymadığı ifade edilmiştir. Alaçatı'ya dinlenmek için gelen ziyaretçilerin de bu durumdan şikâyetçi oldukları ifade edilmiştir.

\section{Bulgu 7:}

Günümüzde ziyaretçi tercihleri ve önceliklerinin değişmesi turizm sektöründe sürdürülebilirlik alanında kalıcı dönüşümler yapılmasına neden olmuştur. Son yıllarda turistlerin çevre ve doğanın korunduğu, yöreye özgü değerlerin tahrip edilmediği destinasyonları tercih ettiği görülmektedir. Yapılan araştırmalarda turistlerin seyahat bölgeleri geri bildirimlerinde dikkat ettikleri noktalar arasında temiz bir çevre, gürültü kirliliğinden uzak olması, otantik bir ortam arayışı içinde oldukları belirtilmiştir (Tusiad, 2012).

Tablo 7. Alaçatı Turizmin Sürdürülebilirliği

\begin{tabular}{|c|c|c|c|c|c|c|c|c|c|c|c|c|c|c|c|c|c|}
\hline & 1 & 2 & 3 & 4 & 5 & 6 & 7 & 8 & 9 & 10 & 11 & 12 & 13 & 14 & 15 & $*$ & $\begin{array}{l}\text { Oran } \\
(\%)\end{array}$ \\
\hline Kontrollü gelişim & $\mathrm{x}$ & & & & $\mathrm{x}$ & & & $\mathrm{x}$ & $\mathrm{X}$ & $x$ & $\mathrm{x}$ & $\mathrm{x}$ & $\mathrm{x}$ & $x$ & $\mathrm{X}$ & 10 & 66,6 \\
\hline Gürültü Önlemi & $\mathrm{x}$ & & & $\mathrm{x}$ & $\mathrm{x}$ & $\mathrm{x}$ & & $\mathrm{x}$ & $\mathrm{x}$ & $\mathrm{x}$ & & $\mathrm{x}$ & & & $\mathrm{x}$ & 9 & 60 \\
\hline Çevrenin korunması & $\mathrm{x}$ & $\mathrm{x}$ & $\mathrm{x}$ & $\mathrm{x}$ & & $\mathrm{x}$ & & $\mathrm{x}$ & $\mathrm{x}$ & & $\mathrm{x}$ & $\mathrm{x}$ & $\mathrm{x}$ & $\mathrm{x}$ & $\mathrm{x}$ & 12 & 80 \\
\hline $\begin{array}{l}\text { Mimari dokunun } \\
\text { korunması }\end{array}$ & $\mathrm{x}$ & $\mathrm{x}$ & & $\mathrm{x}$ & & $\mathrm{x}$ & $x$ & $\mathrm{X}$ & $\mathrm{X}$ & $\mathrm{X}$ & $\mathrm{X}$ & $\mathrm{x}$ & $\mathrm{x}$ & $\mathrm{X}$ & $\mathrm{x}$ & 13 & 86,6 \\
\hline Yerel doku & & & $\mathrm{X}$ & & & $\mathrm{X}$ & $\mathrm{X}$ & $\mathrm{X}$ & $\mathrm{x}$ & $\mathrm{X}$ & $\mathrm{X}$ & $\mathrm{x}$ & & & $\mathrm{x}$ & 9 & 60 \\
\hline
\end{tabular}

* Kodların katılımcilar tarafindan tekrarlanma sayısı.

Alaçatı'ya gelen turistleri amaçlarına göre dinlenmeye gelen turist kitlesi ve eğlenmeye gelen turist kitlesi olarak ikiye ayırmak mümkündür. Bu iki turist kitlesinin talepleri ve Alaçatı'yı ziyaret ettikleri zaman dilimi birbirlerinden farklılık göstermektedir. Katılımcılar Alaçatı'nın sürdürülebilirliğinin sağlanmasının kontrollü gelişmesine bağlı olduğunu belirtmişlerdir. Alaçatı'nın daha fazla genişlememesi, suni, sonradan oluşturulan caddelerin açılmaması gerekmektedir. Alaçatı genişledikçe kendine has özgün yapısının kaybolacağı düşünülmektedir.

Özellikle katılımcıların \% 86,6'sı Alaçatı'nın mimari dokusunun korunmasının önemini vurgulamışlardır. Katılımcılara göre Alaçatı'yı çekici kılan özelliklerin başında mimari yapısı ve kendine özgü yerel dokusu gelmektedir. Günümüzde mevcut mimari yapı için gerekli önlemlerin yerel yönetim ve şehir planlama teşkilatı tarafından alındığı, bu dokuyu bozacak yapılara izin verilmediği vurgulanmıştır. Hem yerel halkın hem de destinasyondaki turizm işletmelerinin mimari bütünlük ve yerel dokuyu bozacak görüntülere izin verilmeyeceği, herkesin bu bilinçte olduğu belirtilmiştir.

Turizm ve çevre arasında çok yakın bir ilişki bulunmaktadır. Turizmin çevreye olumlu ve olumsuz etkileri bulunmaktadır. Turistleri destinasyona çeken doğal ve insan yapımı çevre elemanları turizm sayesinde korunmakta ya da tahrip olmaktadır (WTO, 1998). Destinasyonlarda turizm iyi planlandığı, geliştiği ve yönetildiği zaman turizmin çevre üzerine etkileri olumlu yönde olmakla birlikte doğru planlanmadığı ve kontrolsüz geliştiği zaman çevre üzerine geri dönüşü olmayan etkiler gözlemlenmektedir. 
Katılımcıların \%66,6'sı kontrollü gelişim devam ettiği sürece Alaçatı turizminin sürdürülebileceğini ifade etmişlerdir. Katılımcıların \%80'i ise Alaçatı turizminin sürdürülebilirliği için çevrenin korunması gerektiğini belirtmişlerdir. Çevreyi ve yerel dokuyu bozacak turizm gelişiminin var olan talebinin düşmesine neden olacağı katılımcılar tarafından ifade edilmiştir.

Görüşme 5 "Kanunen bir engel olmamasına karşın otel ile eğlence mekânlarının yan yana olması turistlerin yüksek sesten rahatsı olmasına neden olmaktadır. Turistlerin yanı sıra destinasyonda ikincil konut sahibi olan kişiler de yüksek sesten rahatsız olmaktadırlar."

Katılımcılar Alaçatı'da karşı karşıya kalınan en büyük sorunun gürültü kirliliği olduğunu düşünmektedirler. Yüksek sesten rahatsız olan turistlerin talebinin başka destinasyonlara kaymasından endişe eden katılımcılar çeşitli çözüm önerileri ve kontroller ile bu sorunun üzerine mutlaka gidilmesi gerektiğini vurgulamışlardır. Yaşam alanları ve eğlence mekânlarının iç içe olmasının turizmi olumsuz etkilediği, eğlence mekânlarının ya yaşam alanlarının dışına doğru çıkartılması gerektiği ya da yerel yönetimin daha sıkı denetim yapması gerektiği belirtilmiştir. Yüksek ses sonucu oluşan gürültü kirliliğinin dinlenmek için gelen turistleri olumsuz etkileyeceği ifade edilmiştir.

Görüşme 2 "Destinasyonda kaliteli konaklama ve yiyecek-içecek işletmeleri bulundukça, hizmet kalitesi yüksek oldukça Alaçatı'nın sürdürülebilirliği devam edecektir."

Alaçatı'nın Türkiye'deki diğer turistik destinasyonlara göre fiyat seviyesinin yüksek olması, destinasyonun yüksek gelir grubuna hitap etmesi destinasyonun turistler tarafindan pahalı algılanmasına neden olmaktadır. Katılımcılar Alaçatı'da verilen hizmet ve fiyat dengesinin korunması gerektiğini vurgulamışlardır. İşletmelerin pazarda fiyat kırarak değil kaliteli hizmet vererek turistik talebin devamlılığını sağlaması gerektiğini vurgulamışlar. Kalıcı karlılık ve ekonomik sürdürülebilirliğin turizm işletmelerinin vereceği kaliteli hizmetle ve Alaçatı'nın marka değerinin korunmasıyla gerçekleşeceğini vurgulamışlardır.

Görüşme 9 "Sezonun uzatılması birtakım etkinlikler ile sağlanmalıdır. Sezon 45 günden daha uzun süreye yayılmalıdır. Bunun için Alaçatı'da bulunan turistik işletmelerin kış döneminde de açık olması gerekmektedir."

Katılımcılar tarafından vurgulanan diğer bir nokta ise Alaçatı'da turizm sezonunun uzamasının gerektiği yönünde olmuştur. Destekleyici turizm çeşitlerinin geliştirilmesinin, destinasyonda sezon dışında yapılan festivallere devam edilmesinin, yurt dışı fuarlarına hem işletme bazında hem de destinasyon bazında katılımın artmasının turizm sezonunun uzamasına yardımcı olacağı düşünülmektedir.

\section{Sonuç ve Öneriler}

2000'li yıllar ile birlikte Alaçatı'da bulunan taş evlerin restore edilerek turizm işletmelerine dönüştürülmesi destinasyonda otantik bir yapının oluşmasına neden olmuştur. Değişen turizm trendleri ile birlikte kitle turizm anlayışından uzaklaşarak bireysel turizm anlayışının benimsenmesi turizm talebini destinasyona yönlendirmeye başlamıştır. Yılın 330 günü rüzgar alan destinasyonun sahip olduğu coğrafi ve iklimsel özellikler destinasyonda sörf merkezlerinin açılması ile birlikte rüzgar sörfü yapmak isteyen turistlerin de destinasyonu tercih etmelerine neden olmuştur. Dalgasız denizi, güzel düzenli esen rüzgar sörfüne uygun yan rüzgarı, emniyetli su derinliği ile hem usta sörfçülerin, hem de eğitim almak isteyen ve pratik yapacak olan turistlerin ilgisini çeken destinasyon böylece aktif sörf yapan yerli ve yabancıların talep ettiği bir merkez haline gelmiştir.

Daha önce kullanılmayan ve harap haldeki yapıların aslına uygun restore edilerek özellikli işletmeler haline dönüştürülmesi ile birlikte yüksek gelirli turistlerin ilgisinin destinasyona çekilmesi sağlanmıştır. Ortaya çıkan bu gelişme karşısında turizm talebindeki değişimin farkına varan yatırımcılar yeni turizm yatırımları için destinasyona gelmeye başlamışlardır. Küçük işletmelerin açılması ile birlikte farklı bir yerel dokuya sahip destinasyona yönelik talep yıllar itibari ile artarak çoğalmıştır. Özellikle toplum tarafından bilinilirliği olan kişilerin Alaçatı’yı tercih etmesi ile birlikte destinasyonun popülerliği artmıştır.

Alaçatı yaz aylarında yüksek gelir grubundaki yerli turistlerin tercih ettiği bir destinasyon iken son yıllarda turizm işletmelerinin yurt dışı turizm fuarlarına aktif olarak katılmaları, küçük otellerin birleşerek "Explore Alaçatı" internet sitesini kurmaları ile birlikte bireysel gelen yabancı turistlerinde ilgisini çekmeye başlamıştır. Yaş ortalaması, eğitim ve gelir seviyesi yüksek olan yabancı turistler sakin bir tatil ortamı aradıklarından talebin yoğun olmadığı sezon dışı dönemleri tercih etmektedirler.

Alaçatı'ya yönelik talebi arttıran nedenler arasında; rüzgar sörfü, gastronomi, eğlenme mekânları, plajlar, ulusal ve uluslararası festivaller, yerel doku, mimari yapı ve destinasyondaki küçük otellerin varlığı ve hizmet kalitesi sayılabilir. Destinasyondaki en önemli turistik ürünün rüzgar sörfü olması yanında, son yıllarda gelişmeye başlayan gastronomi turizmi sayesinde de Alaçatı önemli bir cazibe merkezi haline gelmiştir. Gün geçtikçe yerel mutfağın ön plana çıktığı işletme sayısında artış görülmektedir. Gastronomi turizminin her geçen gün daha fazla önem kazandığı günümüz dünyasında 
yerel mutfağa vurgu yapılması ve kaliteli hizmet veren küçük yiyecek içecek işletmelerinin açılması ile birlikte destinasyona yönelik talep artmıştır.

Mimari yapıların aslına uygun olarak korunması, restore edilen taş evlerin sıkı denetimlerden geçirilmesi destinasyonun benzerleri arasında farklılaşmasına neden olmuştur. Özellikle küçük otellere dönüştürülen taş evler sayesinde oluşturulan otantik yapı turistlerin ilgisini çekmektedir. Sonradan inşa edilen evlerin ve yapıların eski taş evlerin mimari özellikleri temel alınarak yapılması destinasyondaki yerel dokunun ve mimari yapının korunmasına olanak sağlamıştır. Yerel yönetimin de üzerinde dikkatle durduğu otantik yapı korundukça Alaçatı'da oluşan marka kimliği sürdürülmeye devam edecektir.

Son yıllarda konaklama tesisi, yiyecek-içecek işletmeleri, eğlence mekânları sayısındaki gözle görülür artış Alaçatı'nın arz kapasitesi yeterli bir seviyeye ulaşmasına neden olmuştur. Ancak, yüksek sezonun başlaması ile birlikte özellikle Temmuz ve Ağustos aylarında taşıma kapasitesinin aşıldığ gözlemlenmektedir. Talep yoğunluğu ile birlikte bazı işletmelerin hizmet kalitesinde düşüşler olması, destinasyona gelen turistlerin memnuniyet düzeylerini olumsuz etkilemektedir. Yerel yönetimin yerleşik nüfusa göre oluşturulan personel kadrosu turizm talebinin yoğunlaştığı yaz döneminde ihtiyac1 karşılayamamakta ve sıkıntıların çıkmasına neden olmaktadır. Bu durum çevre problemlerinin de ortaya çıkmasına neden olmakta; hem gelen turistler hem de destinasyondaki ikincil konut sahipleri hizmet kalitesinin düşmesinden olumsuz etkilenmektedir.

Alaçatı'da turizmin gelişmesi destinasyonda sosyo-kültürel ve ekonomik açıdan birtakım sonuçları da beraberinde getirmiştir. Turizmin destinasyonda süratle gelişmesi ile birlikte yerel halkın eğitim seviyesinde artış gözlemlenmiştir. Yerel halk turizm konusunda farkındalıklarının artması ile birlikte çocuklarını turizm alanında eğitime teşvik etmişlerdir. Kültürel değerlerin önemi turizm sayesinde kavranmış, bu değerlerin korunmasına yönelik çabalar yerel halk tarafından desteklenmeye başlamıştır. Kültürel değerlerin korunmasına yönelik birtakım sivil toplum örgütleri kurulmuş, dernek üyeleri arasında yerel halkın olması sağlanmıştır. Gelen turistler ile kültürel alışveriş farklı kültürlerin kaynaşmasına neden olmuştur. Turizm yatırımlarının sayısının artması ile birlikte yeni iş kolları gelişmiş ve yerel halkın bu iş kollarında istihdam edilme oranı artmıştır.

Olumlu sosyo-kültürel ve ekonomik gelişmelerin yanında birtakım olumsuz gelişmeler de ortaya çıkmıştır. Yerel halkın gelir kaynağının değişmesi bir yandan olumlu olarak görülürken bir yandan da olumsuz sonuçlar doğurmuştur. Tarıma ve hayvancılığa dayalı geçim yerini turizme bırakmıştır. Bu da tarım arazilerinin yerini ikincil konutların almasına ve destinasyonda betonlaşmaya yönelik bir eğilim olmasına neden olmuştur. Yerel halkın sahip oldukları taş evlerini turizm yatırımcılarına kiralamaları ya da satmaları ile birlikte taş evlerin restorasyonu gerçekleşmiştir. Destinasyonda olumsuz olarak görülen en büyük ekonomik etkiler arasında gayrimenkul fiyatlarında gerçekleşen aşırı artış olarak görülmektedir. Gayrimenkul fiyatlarındaki artışla birlikte destinasyondaki kiralar da yükselmiştir. Gayrimenkul fiyatlarının yükselişi ve kiralardaki artış yerel halkın gelir seviyesini arttırmıştır.

Özellikle bu hızlı gelişim süreci ilk yıllarda yerel halkın sadece gayrimenkullerini yatırımcılara kiralayarak ya da satarak gelir elde etmeleri şeklindeyken ilerleyen yıllar ile birlikte halkın turizm konusunda farkındalığının artması yavaş yavaş turizmin içinde yer almaya başlaması sonucunu doğurmuştur. Yerel halk son yıllarda kendi konaklama işletmelerini ve restoranlarını açmakta, düzenlenen festivallere katılmakta yine yerel halktan işletmeler personel istihdam etmektedirler. Halkın turizmden aldığı payın artması, turizmin olumlu ekonomik ve çevresel etkilerini anlaması ile birlikte turizme bakış açısı da değişmiştir.

Turizmin destinasyonda 15 yıl gibi kısa bir sürede bu kadar süratli gelişmesi beraberinde sürdürülebilir kalkınma olgusunun da öneminin anlaşılmasını getirmiştir. Sürdürülebilir kalkınma sürecinde, bir yandan ekonomik kalkınma sağlanmaya çalışılırken, bir yandan yerel halkın refah seviyesinin arttırılması, sosyal ilerlemenin sağlanması ve aynı zamanda çevresel kaynakların korunması amaçlanmaktadır. Alaçatı' da turizm gelişiminin büyük ölçüde sürdürülebilir kalkınma çevresinde geliştiği belirlenmiştir. Destinasyonda yaratılan bilinç sayesinde turizmin çevresel ve kültürel kaynaklar göz önünde tutularak gelişimi gerçekleşmektedir. Özellikle ekonomik ilerlemenin turizmin gelişmesi ve turizm yatırımlarının artması ile sağlandığı vurgulanmıştır. Ancak, turizmin gelişirken artan talep karşısında tarım arazilerinin de bu gelişim süreci içerisinde yapılaşmaya açılmasının ileride olumsuz sonuçlar yaratacağından korkulmaktadır. Her ne kadar yapılan yeni yapılarda eskiye uyumlaştırılarak inşa edilseler bile destinasyonun hızla genişlemesi ve büyümesi kendisine has otantik köy yapının bozulmasına neden olabilecektir. Özellikle destinasyona turistleri çeken faktörün bu yerel doku olduğu düşünüldüğünde; gelişimin belli düzeyde kalması gerekliliği öne çıkmaktadır.

Turizmin gelişmesi ile birlikte destinasyonda meydana gelen değişikler arasında destinasyondaki taş binaların restorasyonu önemli bir yere sahiptir. Yerel halkın gelir yetersizliğinden dolayı restore edemediği gayrimenkuller gelen yatırımcılar tarafından restore edilmiştir. Büyük bir kültürel katkı olarak düşünülen bu restore edilmiş taş evler sayesinde Alaçatı bugün Türkiye'nin en popüler destinasyonlarından biri haline gelmiştir. Restore edilen binaların konaklama tesisi, yiyecek-içecek 
işletmesi ve eğlence mekânlarına dönüştürülmesi ile birlikte destinasyonda gözlemlenen en büyük gelişim turizm işletme sayısındaki artıştır. Bu değişim ile birlikte Alaçatı turizminin büyük bir ivme kazanmıştır. Restore edilen yapılarla birlikte değer kazanan destinasyon sahip olduğu bu otantik yapı ile turizm pazarında yerini almıştır. Mimari yapısı, yerel dokusu, turizm işletmeleri ile markaya dönüşen destinasyon özellikle iç pazardan, son yıllarda ise dış turizm pazarından önemli paylar elde etmeye başlamıştır. $\mathrm{Bu}$ olumlu gelişmelerin yanı sıra destinasyondaki işletmelerin bir takım kaygıları da bulunmaktadır. Hızlı gelişimin Alaçatı'nın yerel dokusunu bozduğunu, otantik yapının kendine özgü havasını yitirildiğini düşünen katılımcılar bir takım önlemler alınmaz ise destinasyonun yaşam döneminin uzamayacağından, yönelik talebin başka destinasyonlara kayacağından endişe etmektedirler.

Olumsuz değişimin önüne geçilmesi için yerel yönetime çok fazla iş düştüğü katılımcıların büyük çoğunluğu tarafından belirtilmiştir. Yerel yönetimin uyguladığı birtakım politikaların Alaçatı'nın kültürel ve doğal varlıklarının korunmasında çok etkili olduğu fakat ileriki dönemlerde de hızlı gelişme sürdüğü takdirde bu politikaların yetersiz kalabileceğini katılımcılar dile getirmişlerdir. Özellikle yerel yönetimin taş binaların restorasyonu esnasında uyguladığı katı denetim kuralları Alaçatı'nın günümüzdeki otantik yapısının yeniden oluşturulmasına ve korunmasına neden olmuştur. Yerel yönetimin destinasyonun mimari yapısına uymayan görünümlere izin vermemesi katılımcıların desteklediği politikalar arasında yer almaktadır. Destinasyonda izin verilmeyen plastik masa ve sandalyeler, 1şıklı tabelalar, seyyar satıcılar, çevreye duman veren yiyecek işletmeleri ile birlikte bir düzen oturtulmaya çalışılmıştır.

Özellikle çevresel sürdürülebilirliğin öneminin farkında olan yerel halk ve destinasyondaki işletmeler tek başına yerel yönetimin sürdürülebilirlik konusunda yetmeyeceğinin de farkındadırlar. Bununla birlikte sosyo-kültürel sürdürülebilirliğin sağlandığı, yerel yönetimin destinasyonun kültürel varlıklarına sahip çıktığı ve korunması için çeşitli uygulamalar yaptığı da katılımcılar tarafından belirtilmiştir. Turizm işletmeleri tarafından dile getirilen ve benimsenen korumacılık yaklaşımının yerel yönetim tarafından da özümsenmesi ile birlikte bir takım değerlerin kaybolması önlenmeye çalışılmaktadır.

Koruma kullanma dengesinin sağlanması, sahip olunan değerlerin korunması halinde destinasyonda ekonomik sürdürülebilirlik de sağlanabilecektir. Özellikle sürdürülebilir ekonomik gelişme çevreye ve doğal kaynaklara zarar vermeden yeni yatırımların destinasyonda faaliyete geçmesi ve yerel halka istihdam sağlaması ile birlikte gerçekleşebilmektedir. Alaçatı'da 2001 yılında bir tek konaklama tesisi mevcut iken 2014 yılında bu sayı 255'e çıkmıştır. Bunula birlikte yiyecek-içecek işletmeleri ve eğlence mekânları sayısının da arttığı gözlemlenmektedir. Ancak, yüksek kira bedelleri yüzünden turizm işletmelerinin her sene el değiştirmesi nedeniyle hizmet kalitesi düşmekte, destinasyona tekrar gelen turistler farklı yatırımcılar ile karşılaşmakta, bu da turistlerin memnuniyetinin düşmesine neden olmaktadır. Turizm talebinin sadece belirli aylarda yoğunlaşması yatırımcıların yaz aylarında açık olup kış aylarında işletmelerini kapatmalarına neden olmaktadır. Ekonomik sürdürülebilirliğin sağlanması için işletmelerin sadece yaz aylarında değil, kış aylarında da açık olması gerektiği, bu şekilde hem istihdam olanaklarının artacağı hem de turizm talebinin kış aylarında da arttırılması sağlanacağı belirtilmiştir.

Alaçatı turizminin ekonomik, sosyal ve çevresel sürdürülebilirliğinin sağlanması ve sahip olunan kaynakların gelecek kuşaklara aktarılabilmesi için bir takım önlemlerin alınması gerekmektedir. Görüşme yapılan katılımcılar özellikle gürültü kirliliğinin ileride büyük problemler yaratabileceğini belirtmişlerdir. Yerel yönetim, turizm işletmeleri ve yerel halkın da üzerinde durduğu en önemli doğal ve kültürel kaynaklar olarak gösterilen çevre ve mimari yapılar dikkat edilmesi gereken noktalar arasında yer almaktadır. Alaçatı'nın çekicilikleri arasında sayılan yerel doku ve mimari yapı üzerinde oluşabilecek herhangi olumsuz bir gelişim turizm talebinin başka destinasyonlara kaymasına neden olacaktır.

Destinasyonlar sürdürülebilir turizmi benimsemeleri ile birlikte bir takım hedefler ve politikaları uygulamak zorundadırlar. Turizmin gelişmesi ile birlikte çevresel ve sosyo-kültürel varlıklarda bir takım baskılar oluşacaktır. Bu baskıların nedenleri turizm işletmelerinden ya da turistlerden kaynaklanmaktadır. Oluşabilecek baskıların minimuma indirgenmesi için bir takım çalışmaların yapılması gerekmektedir. Alaçatı özellikle yaz aylarında yoğun bir talep ile karşı karşıya kalmaktadır. Temmuz ve Ağustos aylarında taşıma kapasitesinin aşılması ile birlikte problemler ortaya çıkmakta, bu da hem gelen turistleri hem yerel halkı hem de destinasyonda ikincil konut sahibi olan kişileri rahatsız etmektedir. Alaçatı'da turizmin belli aylarda sıkışmasını önlemek, turizm mevsimini uzatmak ve 12 aya yaymak için bir takım çalışmaların yapılması gerekmektedir.

Alaçatı'da turizm mevsiminin uzatılması ve talebin yaz ayları dışında kış aylarına da yayılması, destinasyonun sürdürülebilirliğinin sağlanması için atılması gereken en önemli adımlarım başında gelmektedir. $\mathrm{Bu}$ amaca ulaşabilmek için turistik ürün çeşitlendirmesine gidilmelidir. Destinasyonların sahip oldukları doğal ve kültürel kaynak çeşitliliği arttıkça turizm pazarında ki rekabet güçleri de artmaktadır. Bunların dışında sahip oldukları yerel doku, mimari yapı, turizm işletmeleri, alt yapı ve üst yapı olanakları da turistik ürünü oluşturan faktörler arasında yer almaktadır. Destinasyonlar seçilmiş turistik ürüne dayalı turistik ürün çeşitlendirmesine giderek hitap edecekleri turist kitlesini 
farklılaştırabilmektedir. Daha küçük ama gelir seviyesi yüksek turist gruplarına hitap edilecek seçilmiş turistik ürünler yaratılması ile birlikte kitle turizminin olumsuzluklarını azaltmak mümkün olacaktır.

Alaçatı'da turizm mevsiminin uzamasını sağlayacak en önemli araçlardan bir tanesi rüzgar sörfü turizmidir. Yılın 12 ayında da yapılabilen bir turizm çeşidi olarak sörf turizmi Alaçatı'nın yıl boyu canlı kalmasını sağlayacaktır. Sörf turizminin yaz aylarında olduğu gibi yıl boyu devam etmesini sağlamak için özellikle yurt dışı pazarına yönelik tanıtım ve pazarlama faaliyetlerinin yapılması gerekmektedir. Yurt dışı fuarlarına destinasyon bazında ya da turizm işletmeleri olarak katılımın sağlanması ile yabancı turist sayısının artacağı öngörülmektedir.

Bulunan termal kaynakların atıl vaziyetten kurtarılarak işlevsellik kazandırılması destinasyonda yeni bir turizm çeşidi oluşturulmasına kaynaklık edecektir. Termal turizmin gelişmesi ile birlikte destinasyona olacak talep kış aylarında da devam edecektir. Destinasyonda yeni termal otel olarak yatırımlar yapılması yerine mevcut konaklama tesislerine termal özelliği de kazandırılması sezon dışında atıl durumunda olan konaklama tesislerinin kış aylarında da çalışmasını sağlayacaktır.

Alaçatı'da üzerinde durulması gereken bir başka turizm çeşidi ise gastronomi turizmidir. Özellikle yerel mutfağı ön plana çıkartan kaliteli işletmeler, yüksek hizmet kalitesi bekleyen üst gelir grubundaki gastronomi turistlerinin destinasyona yönelmesini sağlayacaktır. Destinasyonda açılacak yerel mutfağı yansıtan işletme sayısının artırılması ve bu işletmelerin yurt içi ve yurt dışı pazarında tanıtımının yapılması talebin artmasına neden olacaktır. Diğer taraftan yerel mutfağı ön plana çıkartan ulusal ve uluslararası festivallerin turizm sezonu dışında düzenlenmesi talebin sezon dışında da destinasyona yönelmesini sağlayacaktır.

Şarap bağlarının işlevselliğinin arttırılması ve şarap turizminin geliştirilmesi sağlanarak seçili ürüne dayalı turizm çeşitlendirmesinin destinasyonda gerçekleşmesi desteklenebilir. Turistlere yönelik yapılacak bağ bozumu, bağ dikimi, üzüm toplama ve şarap yapım etkinlikleri ile yerli ve yabancı turistlerin destinasyonu turizm sezonu diye tabir ettiğimiz haziran, temmuz ve ağustos aylarının dışında da ziyaret etmesi sağlanabilir.

Alaçatı'yı ziyaret eden yabancı turistlerin sayısını arttırmaya yönelik faaliyetlerin hem turizm işletmeleri hem de yerel yönetim tarafindan düzenlenmesi gerekmektedir. Orta yaş ve üstü turist grubunun Alaçatı'nın sakin olduğu dönemleri tercih ettiği göz önünde bulundurularak hedef kitleye yönelik tanıtım ve pazarlama faaliyetlerinin yapılması gerekmektedir.

Görüşme yapılan kişilerin ortak görüşü Alaçatı'nın arz kapasitesinin yeterli olduğu yönündedir. Yaz aylarında taşıma kapasitesinin aşılması kış aylarında ise işletmelerin kapanması belirtilmiştir destinasyonda turistik ürün çeşitlendirmesine gidilerek turizm sezonunun uzaması gerektiğini karşımıza çıkarmaktadır. Turizm sezonunun uzaması ile birlikte talep bütün aylara yayılacak, destinasyondaki işletmeler 12 ay boyunca açık olacaktır. Ekonomik sürdürülebilirliğin sağlanması için turizm yatırımlarının sezon dışında açık olması gerekmektedir. Böylece yerel halkın da bu işletmelerde istihdam edilmesine olanak sağlayacak ve mevsimlik işsizlik azalacaktır. Görüşme yapılan kişilerin yakındıkları en önemli konular arasında sürekli el değiştiren turizm işletmeleri yer almaktadır. Yüksek kira bedellerini kışın karşılayamayan işletmeler her yıl el değiştirmekte, gelen turistler her sezon farklı yatırımcılarla karşılaşmaktadır. Bu durum hem hizmet kalitesinin düşmesine hem de Alaçatı'nın marka kimliğinin zedelenmesine neden olmaktadır. Turizm mevsiminin uzaması ile birlikte işletmelerin yaşam döneminin uzaması sağlanabilecektir. Bunula birlikte hizmet kalitesinin düşmemesi için kaliteli yatırımların destinasyonda açılması teşvik edilmelidir.

Sürdürülebilir kalkınmanın önemli bir ayağı olan kaynakların korunmasının hem yerel yönetim, hem turizm işletmeleri hem de yerel halk tarından öneminin anlaşılması gerekmektedir. Yerel halka ve turizm işletmelerine yapılacak bilinçlendirme çalışmaları ile turizmin sahip olduğu kaynakların öneminin kavranması ve bu kaynakların tahrip olamaması için neler yapılması gerektiği üniversitelerin vereceği çeşitli eğitimler ile sağlanabilir.

Katılımcıların bahsettiği en büyük sorunlar arasında destinasyonda ki gürültü kirliliği yer almaktadır. Konaklama işletmelerinin ve eğlence mekânlarının Alaçatı gibi küçük bir destinasyonda yan yana olması, eğlence mekânlarının merkezin bu kadar içinde olması hem ikincil konut sahiplerini hem de konaklama işletmelerinde kalan turistleri rahatsız etmektedir. Eğlence mekânlarının şehrin merkezinden yan yollara konutların ve konaklama işletmelerinin dışına kaydırılması ya da yerel yönetimin sıkı denetimi ile problemin çözümü bir nebze de olsa sağlanabilir. Yerel yönetimin ruhsat verirken alacağı bir takım önlemler, daha sonra yapacağı denetlemeler ile gürültü probleminin azaltılabileceği düşünülmektedir.

Yine aynı şekilde destinasyonun en önemli çekim kaynağı olan taş evlerin de restorasyonu yerel yönetimin sıkı denetimi altındadır. Ancak sonradan yapılan yapılar eski tarz taş evlere uydurulmaya çalışılsa da otantik yapının erozyona uğramasına neden olmaktadır. Ortaya çıkan suni hava destinasyonun ileride otantik yapısının kaybolmasına neden olacaktır. Mimari dokunun öneminin farkında olan yerel yönetim Alaçatı'nın Kuşadası gibi betonarme bir destinasyona dönüşmemesi için mutlaka aldığı önlemler arttırılmalıdır. Fiziki bütünlügün sağlanması için kırsal alanların, Alaçatı'nın köy 
dokusunun korunması gerekmektedir. $\mathrm{Bu}$ şekilde hem çevrenin fiziki özelliğinin bozulmasına engel olunacak hem de görsel bakımdan çekiciliğinin kaybolmaması sağlanacaktır.

Bununla birlikte destinasyonda sürdürülebilir turizmin gerçekleşmesi planlı bir gelişme sürecine bağlıdır. Doğru plan ve politikaların benimsenmesi ile turizmin çevreye ve kaynaklara zarar vermeden gelişmesi ve ilerlemesi sağlanabilecektir. Yerel yönetimin, turizm bakanlığının, destinasyonda ki turizm işletmelerinin ve yerel halkın içinde bulunacağı bir danışma kurulu oluşturulması gerekmektedir. Sürdürülebilir turizm için bütün paydaşların fikirlerinin alınması, en sağlıklı çözüme ulaşılmasını sağlayacaktır. Bu şekilde oluşturulacak danışma kurulu ile paydaşlar arasındaki iletişim sağlanarak destinasyona yönelik daha sağlıklı plan yapılma ve politika belirleme imkanı bulunabilir. Özellikle yerel yönetim ve destinasyondaki turizm işletmelerinin sürdürülebilir turizm için planlama, yönetim ve uygulama aşamalarında olmaları sürdürülebilir turizmin hedeflerine başarı ile ulaşılmasını sağlayacaktır.

\section{Kısıtlar ve Gelecek Çalışmalar}

Araştırma gerek turizm işletme sahiplerinin gerek sivil toplum kuruluşlarının turizmde düşük sezon olarak kabul ettiği kış aylarında yapılmıştır. Sezon dışında işletme sahiplerinin Alaçatı'da turistik tesislerini kapatması sonucu 15 kişi ile görüşme yapılmıştır. İleriki çalışmalarda yerel halkın ve destinasyonu ziyaret eden turistlerin Alaçatı turizmine bakış açısı ve sürdürülebilir turizm anlayışına olan bakış açıları yüksek sezonda incelenebilir. Ayrıca destinasyonda oluşturulacak yeni turistik ürünlere yönelik talebin mevsimlere göre özellikleri belirlenerek iç ve dış turizm pazarına göre ayrı turistik ürün stratejileri oluşturulması için çalışmalar yapilabilir. 


\section{Kaynakça}

Aktaş, Gürhan (2007). Turistik Çekicilikler, Genel Turizm, (Ed. Orhan İçöz), Ankara , 99-115.

Avcıkurt, Cevdet. (2007). Turizm Sosyolojisi, Detay Yayıncılık, Ankara.

Baker, Micheal J., Emma Cameron, (2008), Critical Success Factors in Destination Marketing, Tourism and Hospitality Research, 8(2), 79-97.

Buhalis, Dimitrios (1999). Limits of Tourism Development in Peripheral Destinations: Problems and Challenges, Tourism Management, 20(2), 183-185.

Buhalis, Dimitrios (2000), Marketing the Competitive Destination of the Future, Tourism Management, 21(1), 97-116.

Çetin, Murat (2006) . “Teori ve Uygulamada Bölgesel Sürdürülebilir Kalkınma”, C. Ü. İktisadi ve İdari Bilimler Dergisi, 7(1), 1-7.

David L. Edgell Sr. (2006), Managing Sustainable Tourism a Legacy for the Future, Haworth Press: NewYork.

Doğan, Hasan Zafer (2004). Turizmin Sosyo-Kültürel Temelleri, Detay Yayıncılık, Ankara.

Fernardo Vera Rebollo ve Josep A. Ivars Baidal, (2003) Measuring Sustainability in a Mass Tourist Destination: Pressures, Perceptions and Policy Responses in Torrevieja, Spain, Journal of Sustainable Tourism, 11(2), 181-203.

Hardy, A.L.ve Beeton, R.J.S. (2009). Sustainable Tourism or Maintainable Tourism: Managing Resources For More Than Average Outcomes, Journal of Sustainable Tourism, 9 (3) ,168-192.

http://www.channelingreality.com/Documents/Brundtland_Searchable.pdf DEVELOPMENT AND INTERNATIONAL ECONOMIC CO-OPERATION: ENVIRONMENT Report of the World Commission on Environment and Development, Erişim 10.03.2014.

Hunter, Colin, (2002). Sustainable Toursim and The Touristic Ecological Footprint, Environment and Sustainable Development, 4(1), 7-20.

Kaya, İsmet (1997). Sürdürülebilir Turizm Kalkınması ve Ülkemiz Açısından Bir Değerlendirme, (Yayınlanmamış Doktora Tezi), Balıkesir Üniversitesi Sosyal Bilimler Enstitüsü Turizm İşletmeciliği ve Otelcilik Anabilim Dalı, Balıkesir.Mazilu, Mirela (2010). "Towards a model of an optimalsustainable tourist destination" publish in. Proceedings of International Conference: Cultural, Urban and Tourism Heritage, 28-34.

Mazilu, Mirela (2012), Sustainable Tourism of Destination, Imperative Triangle Among: Competitiveness, Effective Management and Proper Financing, http://cdn.intechopen.com/pdfswm/29224.pdf , 5-35, (Erişim:10.04.2013).

Mazilu, Mirela (2010). "Towards a model of an optimal-sustainable tourist destination" publish in. Proceedings of International Conference: Cultural, Urban and Tourism Heritage, 28-34.

Mil, Burak (2007). "Nitel Araştırma Tekniği Olarak Görüşme”, Nitel Araştırma, (Ed. Atilla Yüksek, Burak Mil, Yasin Bilim), Detay Yayıncılık, Ankara.

Tüsiad, Sürdürülebilir Turizm, (2012), 26-27.

Usta, Öcal (2009). Turizm Genel ve Yapısal Yaklaşım, Detay Yayıncılık, Ankara.

World Tourism Organization (1993), Sustainable Tourism Development: Guide for Local Planners, Spain.

Yıldırım, Ali ve Hasan Şimşek (2013). Sosyal Bilimlerde Nitel Araştırma Yöntemleri, Seçkin Yayınevi, 9. Baskı Ankara.

Yüksek, Murat (2010) . Sürdürülebilir Kalkınma ve Türkiye'de Çevre Politikaları, (Yayınlanmamış Yüksek Lisans Tezi), Gaziantep Üniversitesi Sosyal Bilimler Enstitüsü İktisat Anabilim Dalı, Gaziantep. 


\section{EK 1. GÖRÜŞME FORMU}

1. Alaçatı gelişme sürecini ve mevcut durumu değerlendirir misiniz?

2. Alaçatı'yı çekici kılan özellikler nelerdir?

3. Alaçatı'ya gelmeyi kimler tercih ediyor?

4. Turizm gelişirken sosyo-kültürel ve ekonomik yapıda ne gibi değişiklikler meydana gelmiştir?

5. Turizmin gelişmesinde halkın payı ile ilgili görüşleriniz nelerdir?

6. Son 15 yılda turizmin gelişmesi ile birlikte yerel doku üzerinde ne gibi değişiklikler meydana gelmiştir, bahseder misiniz?

7. Alaçatı'nın doğal ve kültürel çekim gücü korunarak gelecek kuşaklara aktarılması ve sürdürülebilirliğinin sağlanması için neler yapılmalıdır? 


\begin{tabular}{|l|l|l|}
\hline 1 & Hüsnü BAYLAV & Alaçatı Turizm Derneği Eski Başkanı \\
\hline 2 & Mahmut ETKİN & Alaçatı Turizm Derneği Üyesi- Sailors Otel Alaçatı Sahibi \\
\hline 3 & Beycan İNALUK & Mavi Ev Butik Otel Sahibi \\
\hline 4 & Mustafa Kemal AŞKAN & Rotary Üyesi- İkincil Konut Sahibi \\
\hline 5 & Cengiz UZİ̧̧ & Kuytu The Hotel Ve Kuytu Restoran İşletme Sahibi \\
\hline 6 & İnci Sezer BECEL & Çeşme Kaymakamı \\
\hline 7 & Muhittin DALGIÇ & Çeşme Belediye Başkanı \\
\hline 8 & Hasan ÖLMEZER & İmren Han Butik Otel ve İmren Pastanesi Sahibi \\
\hline 9 & Celal UYSAL & Alaçatı E travel Şirket Kurucusu \\
\hline 10 & Celal & Alaçatı Turizm Derneği Başkanı- Beyevi Butik Otel İşletme Sahibi \\
\hline 11 & BAYRAKTAROĞLU & \\
\hline 12 & Tomris MAREVENT & Köşe Kahve İşletmesi Sahibi \\
\hline 13 & Ömer ÖNAL & $\begin{array}{l}\text { Alaçatı Sanat Ve Kültür Derneği Kurucu Başkanı - Alaçatı Kitap Evi } \\
\text { Sahibi }\end{array}$ \\
\hline 14 & Veysi ÖNCEL & Çeşme Turistik Otelciler Birliği Başkanı (ÇEŞTOB) Başkanı \\
\hline 15 & Ahmet PALAMUTÇU & Alaçatı Sesle Mücadele Derneği Başkanı \\
\hline
\end{tabular}

